Portland State University

PDXScholar

$11-25-1985$

\title{
The Effects of Income Inequality on Racial Residential Segregation in the Portland Metropolitan Area
}

Katayoun Aidinezhad

Portland State University

Follow this and additional works at: https://pdxscholar.library.pdx.edu/open_access_etds

Part of the Sociology Commons

Let us know how access to this document benefits you.

Recommended Citation

Aidinezhad, Katayoun, "The Effects of Income Inequality on Racial Residential Segregation in the Portland Metropolitan Area" (1985). Dissertations and Theses. Paper 2876.

https://doi.org/10.15760/etd.2872

This Thesis is brought to you for free and open access. It has been accepted for inclusion in Dissertations and Theses by an authorized administrator of PDXScholar. Please contact us if we can make this document more accessible: pdxscholar@pdx.edu. 
THE EFFECTS OF INCOME INEQUALITY ON RACIAL RESIDENTIAL SEGREGATION IN THE PORTLAND METROPOLITAN AREA

by

KATAYOUN AIDINEZHAD

A thesis submitted in partial fulfillment of the requirements for the degree of

\author{
MASTER OF SCIENCE \\ in \\ SOCIOLOGY
}

Portland State University 
AN ABSTRACT OF THE THESIS OF Katayoun Aidinezhad for the Master of Science in Sociology presented November 25, 1985.

Title: The Effects of Income Inequality on Racial

Residential Segregation in the Portland Metropolitan Area.

APPROVED BY MEMBERS OF THE THESIS COMMITTE:

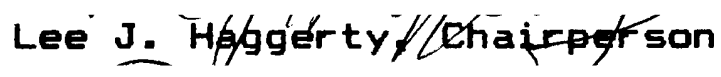

Hobert W. Shotola

Don C. Gibbons

Changes in the patterns of income and residential segregation were examined in the Portland Metropolitan Area. The 1970 and 1980 Census of Population and Housing were used in calculating the indexes of dissimilarity between black and white populations. The data indicated a significant decrease in the residential segregation of blacks in suburban areas between 1970 and 1980 . The central city area still remained highly segregated with a segregation index of 69.5 . 
Taeuber"s index of dissimilarity was used in calculating the unevenness in the distribution of income between blacks and whites. Suburbia showed a significant decrease in income segregation compared to the central city area. Overall, both residential and income segregation were dropping at a much faster rate in the suburban areas than the central city areas.

To examine the effects of socio-economic status on residential segregation, a sample of 138 blacks was drawn from the population of higher status blacks in the city of Portland. Residential choices of the influential blacks were examined to determine whether or not their influential status was accompanied by a tendency toward greater integration as opposed to greater segregation. The 1980 Census Tract Street Index was used in this analysis. The data show that despite the improvement in socio-economic status, a majority of these blacks still lived in the "ghetto" area(59\%) and only $14 \% 1$ ived in suburbia.

Therefore, the data show no significant relationship between the gains in the status and the tendency toward more integration. This tendency bears directly upon the issue of voluntary segregation.

The data shows strong support for hypothesis two holding that change in income inequality results in change in residential segregation. That is, if we reduce the 
income differentials between black and white populations, racial residential segregation will be minimized. 
THE EFFECTS OF INCOME INEQUALITY ON RACIAL RESIDENTIAL SEGREGATION IN THE PORTLAND METROPOLITAN AREA

by

KATAYOUN AIDINEZHAD

A thesis submitted in partial fulfillment of the requirements for the degree of

\author{
MASTER OF SCIENCE \\ in \\ SOCIOLOGY
}

Portland State University 
TO THE OFFICE OF GRADUATE STUDIES AND RESEARCH :

The members of the Committe approve the thesis of Katayoun Aidinezhad presented November 25, 1985.

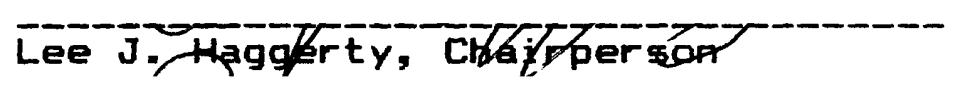

Robert W. Shotola

Don C.

APPROVED:

Grant M. Farr, Head, Department of Sociology

Jim/F/. Heath, Dean of Graduate Studies and Research 


\section{ACKNOWLEDGEMENTS}

I am very grateful to my committe members $\mathrm{Dr}$. Haggerty, Dr. Shotola, and Dr. Gibbons for all the help and insights they gave me in completing my thesis. I would also like to thank my dear friend Erik Johannes for helping me type this thesis. Finally, I would like to thank my parents for their continous love and encouragement. I dedicate this thesis to my parents Abdul Mohammad Aidinejad and Farang Makvandi . 
TABLE OF CONTENTS

PAGE

ACKNOWLEDGEMENTS. ......................... i i

LIST OF TEXT TABLES....................... v

LIST OF APPENDIX TABLES................... vi

LIST OF FIGURES.........................vii

CHAPTER

I INTRODUCTION. ..................... 1

I I REVIEW DF THE LITERATURE. ............ 6

I I METHODOLOGY......................... 14

IV FINDINGS..................... 18

v DISCUSSION....................... 31

BIBLIOGRAPHY............................. 34

APPENDIX.............................. 40 


\section{LIST OF TEXT TABLES}

TABLE

PAGE

I Black Population Distribution in 1970 and 1980 SMSA.................. 25

I Bl ack Median Family Income

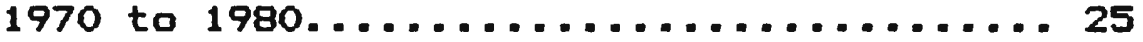

I I White Median Family Income

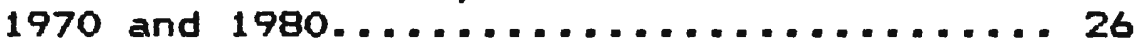

IV Ratio of Black Median Family Income to White Family Income........... 26

$\checkmark$ Indexes of Income Segregation

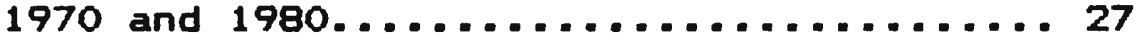

VI Indexes of Residential Segregation 1970 and $1980 \ldots . . \ldots . . \ldots . . \ldots . . \ldots 27$

VII Indexes of Income and Residential

Segregation 1970 and $1980 \ldots \ldots . \ldots . \ldots 28$

VIII Percentage Point declines in Segregation 1970 and $1980 . \ldots . . . \ldots . . .28$

IX Indices of Residential Segregation for Tracts Containing any Influential Blacks.. 29 


\section{LIST OF APPENDIX TABLES}

TABLE

PAGE

I - VI Indexes of Residential Segregation 1970.

VII - XII Indexes of Residential Segregation 1980.

$X V$ - XXI Index of Income Segregation

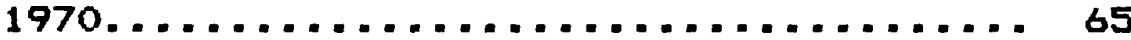

XXII - XXVII Index of income segregation

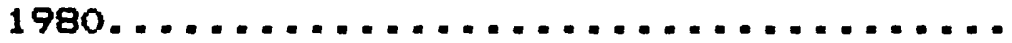

XXIX Residential Segregation and $\mathrm{Higher}$

Status Bl acks vs. Whites............. 73

$\mathrm{XXX}$ Residential Segregation of $\mathrm{Bl}$ acks

vs. whites....................... 75

XXXI Residential Segregation of Higher

Status Blacks vs. Blacks............. 77 


\section{LIST OF FIGURES}

F IGURE

PAGE

I PERCENTAGE POINT DECLINES IN

INCOME AND RESIDENTIAL SEGREGATION....... 30 
CHAPTER I

\section{INTRODUCTION}

The race riots of the 1960's captured the attention of millions of people throughout the nation. Racial unrest brought fear and bewilderment to the leaders of the country. For the first time in the history of the nation, political leaders took the nature of race relations very seriously. Fears of racial division and anarchy brought black Americans to the center of attention of the federal government. The political leaders turned to race relation experts for answers to the dilemmas confronting them. They wanted to know : "What happened?" "Why did it happen?" and "what can be done to prevent it from happening again?".

On July 27,1967, President Lyndon B. Johnson appointed an advisory commission to report on the status of blacks, most of whom resided in ghettos in American cities. The commission was to uncover the social, economic, and political factors that led the blacks to revolt, and to devise actions that could be taken to stop the violence.

After several months of intense investigation, the National Advisory Commission came to the conclusion that "Our nation is moving toward two societies, one black one 
white- separate and unequal." According to the Riot Commission, racial division came about through discrimination and segregation, the result of over 300 years of inequities between blacks and whites.

The National Advisory Commission reported (1968:8) :

Social and economic conditions in the riot cities constituted a clear pattern of severe disadvantage for negroes compared with whites, whether the negroes 1 ived in the area where the riot took place or outside it. Negroes had completed fewer years of education and fewer had attended high school. Negroes were twice as likely to be unemployed and three times as likely to be unskilled and in service jobs. Negroes averaged 70 percent of the income earned by whites and were more than twice as likely to be 1 iving in poverty. Although housing cost negroes relatively more, they had worse housing three times as likely to be overcrowded and substandard, when compared to white suburbs, the relative disadvantage is even more pronounced.

Through discriminatory practices blacks were excluded from white residential areas. "Just as significant is the withdrawal of white families from, or their refusal to enter neighborhoods where negroes are moving or already residing." (NAC, 1968:244) Racial segregation also came about through (1968:204):

The massive and growing concentration of impoverished negroes in our cities resulting from negro migration from the rural south, rapid population growth and the continuing movement of white middle class to the suburbs.

As a result, "Central cities are becoming more heavily black while the suburban fringes around them remain almost entirely white." (NAC, 1968:243) 
According to the NAC (1968:203):

The continuing exclusion of great numbers of negroes from the benefits of economic progress through discrimination in employment and education, and their enforced confinement in segregated housing and schools.

The reports by the National Advisory Commission indicated that racial discrimination was the main cause of the turmoil of the 60\% 5 . They argued that racial problems can be "solved only if white Americans comprehend the rigid social, economic, and educational barriers that have prevented negroes from participating in the mainstream of American life." (NAC, 1968:207)

The civil rights movement of the 60's brought some major changes in the status of blacks in America. Blacks protested against oppression and inequality and sought recognition in the society. Black leaders demanded justice and equal oppurtunities for their people. After a few years of struggle their needs were responded to through some major changes in the 1 aws of the nation. As a result, some blacks were able to advance themselves socially, economically, and politically. But, despite the advancement of some, the majority still remain in their disadvantaged position. Today, after two decades, a majority of blacks are still exposed to high levels of unemployment and poverty in the central cities. According to Blackwell and Hart (1982:3):

The black unemployment rate is still close to 
double the white unemployment rate. The black 1 abor force remains largely employed in lower level occupational roles, and the median black family income is less than three-fifths of the median family income of white Americans.

The election of Ronald Reagan in 1980, and the shift to the political right in the American Congress "signaled" a turning point in American race relations. Cuts in social programs (welfare, food stamps, medicare, public housing, etc.) make it "extremely difficult for any number of poor people to maintain a reasonable semblance of decent 1 iving." (Bl ackwel 1, Hart, 1982:190)

Black Americans have become increasingly disenchanted and fearful of the policies of the Reagan administration. According to a poll taken in February 1981 by the Gallup organization for Newsweek magazine, "62 percent of the blacks and only 9 percent of all whites in the sample expected things to worsen for them under the Reagan administration." (Blackwell, Hart, 1982:186)

A 1981 report of the NAACP indicates that the economic status of blacks in America is approaching a state of "disaster." Are we approaching another racial crisis in the $1980^{\prime} 5$ ? Did the racial protests of the $1960^{\prime} 5$ fail in bringing justice and equality for black people?

Blackwell and Hart argue that frustration caused by the economic disadvantages "boils over in destruction and 
violence." They argue (1982:194):

Although no one in America would like to witness the conflagrations that occurred in the nation's cities during the 1960's, it may very well happen again if voiceless, powerless poor people of all races begin to ventilate their increasing hostilities against Reagonomics in violent acts. If their concerns are not addressed, even greater strains in race relations are ahead.

This thesis explores two major aspects of racial discrimination, income inequality and residential segregation, and examines their inter-relationship. 
CHAPTER I I

REVIEW OF THE LITERATURE

Income inequality has been viewed as one of the main factors contributing to the separation of the black and white population in American cities. According to Eunice and George Grier, economic status of blacks "posed a giant barrier to the free dispersal of the growing negro population." (Grier \& Grier, 1966:535) They state further, "with legal barriers lowered, economic differentials between the races remain a major obstacle" in desegregation. (Grier \& Grier, 1964:17) Similarly, racial income inequality according to Michael Reich, "is still very much with us. Instead of narrowing, important racial income differentials in the United States have persisted throughout the Twentieth century." (Reich, 1981:19)

To what degree does economic status of blacks influence the existing patterns of residential segregation between blacks and whites? What are the main reasons for high degrees of residential segregation between blacks and whites?

\section{Causes of Segreqation}

Two popular themes have been developed by sociologists 
with regard to residential segregation of blacks in American cities. Segregation is sometimes viewed as voluntary and sometimes as involuntary on the part of minorities in relation to the majority. Voluntary segregation is when the minority group chooses to 1 ive amoung "compatriots." Banfield contends (1974:90), "many negroes prefer black neighborhoods, and would $l$ ive in them even if their oppurtunities to 1 ive in white areas were excellent." Such a view according to Farley, Bianchi, and Colasanto (1979) is not supported by empirical investigations. (1979:101):

A national study conducted in 1969, for instance, found that three-quarters of black respondents wished to 1 ive in integrated neighborhoods, while only one black in six expressed a preference for an all black area.

A majority of sociologists, on the other hand, argue that racial segregation has been imposed on blacks in the U.S. through discriminatory practices. For example, Lieberson and Carter argue (1982:512):

In the case of black-white residential segregation, researchers have been obliged to assume that it is largely involuntary on the part of blacks, with the high levels reflecting a white distaste for living near blacks coupled with the ability of whites to impose their will through various discriminatory forces.

There have been three prominent explanations for non-voluntary racial residential segregation : housing discrimination, white racism, and economic disadvantages of the blacks. 
Housing Discrimination

Karl Taeuber (1965:9) claims that discrimination in

housing is the major cause of black segregation in cities.

Neither free choice nor poverty is a sufficient explanation for the universally high degree of segregation in American cities. Discrimination is the principle cause of negro residential segregation, and there is no basis for anticipating major changes in the segregated character of American cities until patterns of housing discrimination can be altered.

\section{John Denton in Apartheid American Style argued}

that the members of minority races don't have free choice of residence in any part of the country. Through discrimination, private groups bar the entry of minorities into white neighborhoods. According to Denton (1967:1):

National Association of Real Estate Boards (NAREB) working through state and local boards, have been the undisputed leader of the private groups. NAREB has used economic, social, political and legal power to fashion the American style of apartheid.

The theory of separate but equal was reflected in the attempts made by some legislators to establish residentially segregated areas for blacks and other minorities. (Forman, $1971: 53)$ :

Some cities in the South and on the West Coast actually passed ordinances stating that non whites could only live in certain specified areas in the city. San Francisco was the first, in 1890, with a 1 aw that Chinese could live only in a certain part of the city and requiring those who lived elsewhere to move to the area designated for Chinese. Legislation in southern cities attempted to establish either all-negro or all-white blocks or to establish segregated districts in which it was 
illegal for members of the prohibited race to live ? this could force whites to move if they 1 ived in area designated for blacks). Despite the fact that such legislation was declared unconstitutional by the U.S. Supreme Court by 1917, attempts were still made to establish segregated areas by 1 aw as 1 ate as 1935 in Oklahoma City and 1949 in North Carolina.

In the North, segregation was enforced through institutional means (property laws) to keep blacks segregated in the cities. For example, according to Forman (1971:53), "the restrictive covenant was placed on property owned by whites to keep it from being sold to undesirables." Restrictive covenants in the cities "had a profound effect upon the racial residential patterns" and "contributed immensely to increasing the tensions and hatreds in both races." (Forman, 1971:54) In 1948 the U.S. Supreme Court ruled that the practice of restrictive covenants was unconstitutional.

Blockbusting was applied by real-estate agents who specialized in expanding the black neighborhoods by selling property to blacks around white blocks. Blockbusting was used to pressure whites into selling their property to blacks. The blockbuster acts as a medium in the selling process and profits by his actions. The legal definition of blockbusting is in the 1968 Fair Housing Act (Forman, $1971: 84)$ :

For profit, to induce or attempt to induce any person to sell or rent any dwelling by representations regarding the entry or prospective enty into the neighborhood of a person or persons of 
a particular race, color, religion, or national origin.

Michael Reich asserts that racial inequality was reinforced by goverment housing policies. Blacks were excluded from the housing subsidized by the Federal Housing Administration (FHA) programs. FHA permitted racial covenant clauses. These clauses "constituted agreements not to admit blacks to predominantly white neighborhoods." The FHA helped to form the patterns of residential segregation in the metropolitan areas. (Reich, 1981:71)

\section{Racial Prejudice}

Racial segregation was maintained through social disapproval by whites. According to McEntire (1960:74):

In most all-white neighborhoods, to sell or rent to a non-white would be considered a serious offense to the neighborhood. An owner, consequently, who is considerate of his neighbors or who values their good opinion would not wish to introduce a non-white into the neighborhood.

Myrdal in An American Dilemma argued that informal social pressure from whites was perhaps the chief force maintaining residential segregation of negroes. He noted that (1944:622):

Few white property owners in white neighborhoods would ever consider selling or renting to negroes; and even if a few negro families did succeed in getting a foothold, they would be made to feel the spontaneous hatred of the whites both socially and physically.

Physical threats were made against blacks residing in 
white areas. In June of 1945, the Chicago Defender reported that 30 homes of blacks had been attacked by stoning, bombing, and burning. Similarly, in 1957, the New York Times reported that (McEntire 1960:76):

In Pennsylvania, when the first family bought a house in all-white Levittown, crowds numbering in the hundreds gathered nightly in front of the house shouting about and occasionally throwing stones.

The U.S. Riot Commission observed that the concentration of blacks in central cities is 1 argely due to the negative attitudes of whites towards blacks. (1968:247):

The concentration of negroes in central cities results from a combination of forces. Some of these forces, such as migration and initial settlement patterns in older neighborhoods, are similar to those which affected previous ethnic minorities. Others, particularly discrimination in employment and segregation in housing and schools-are a result of white attitudes based on race and color. These forces continue to shape the future of the central city.

Rabert K. Merton's concept of the "self-fulfilling" prophecy has been used by some urban sociologists to explain the fear of integration among the white population. (Forman, 1971:74):

One can see the self-fulfilling prophecy at work on the residential segregation scene. The white indentifies the social pathology of the slum with blacks and fears that if one black family moves into his area it will go all black and become a slum.

\section{Poverty and Segregation}

Low socio-economic status has been viewed by some as the determining factor in segregation of blacks in central 
cities. Davis McEntire in Residence and Race

(1960:71) observed that, the segregation of a group may result from economic weakness. The segregation of negroes, like that of other groups, is traceable to low incomes, group cohesion, and external pressures.

White suburbanization in the period after World War II has also contributed to the segregation of blacks in central cities. William Frey argued (1980: 1396):

City directed in migration of low skilled southern blacks and white suburbanization process, led to high concentration of those blacks and their low per capita incomes within central boundaries.

Similarly, Eunice and George Grier observed that white suburbanization resulted in the concentration of low income blacks in the central city areas. (1966:525):

The great majority of new postwar suburban housing was built for those who could afford to pay the full economic price. The private enterprise system operated to reinforce existing trends which concentrated the low income families in cities, and encouraged the movement of the more wealthy to the outskirts of the city.

Poverty of blacks was viewed by Charles Silberman as the main cause of blacks settlements in the central city areas. He explained (1964:32):

Like all previous immigrant groups, the negroes have settled in the traditional "port of entry"-the oldest, least desirable sections of the city, generally in or around the central business district. That is where the cheapest housing usually is to be found; more important, that is the only place the newcomers can find a place to live, since prejudice as well as income keeps them out of 
the 'better' neighborhoods.

Major causes of residential segregation were discussed in this chapter. Housing discrimination, white racism, and economic disadvantages of blacks were among the most common explanations for involuntary residential segregation. Voluntary segregation was also reviewed as a plausible explanation. My main concern in this thesis was to examine the relationship between income inequality and residential segregation between blacks and whites. The economic status of blacks was considered as a major contributing factor to the separation of blacks in the cities. The specific hypotheses guiding this analysis were:

\section{Hypotheses}

(1) The economic status of blacks shapes their pattern of residential segregation.

(2) Gains in the economic status of blacks result in changes in the patterns and degrees of residential segregation.

(3) Higher status blacks are less segregated from whites than are lower status blacks. 
CHAPTER I I I

METHODOLOGY

The purpose of this study was to examine the effects of racial income inequality on residential segregation in the Portland SMSA. The 1970 and 1980 census data were used to examine changes in the degrees and patterns of income and residential segregation between blacks and whites during that time period.

\section{Measurement of Seqregation}

Taeuber's index of dissimilarity was used to measure the uneveness in the residential distribution of black and white populations in the Portland Metropolitan Area. The same index was used to measure the uneveness in income distribution between the two groups. The index of residential and income segregation can assume values between 0 and 100. The higher the value, the higher the degree of segregation, the lower the value, the greater the degree of "inter-mixture." The symbol used to represent the index is the Greek Delta. Taeuber explained (1968:8):

The index is calculated from census data showing the distribution of negro and non-negro households among the census tracts of the city (or metropolitan area). If each neighborhood (census tract) is all white or all negro, the index will be 100. If each neighborhood is racially mixed to the same degree as every other, each with the same percentage of 
negroes as the entire city-the index will be 0 . The specific index indicates the minimum percentage of the city's white household (or alternatively of the city's negro households) that would have to be shifted from tracts of over representation to tracts of under representation to effect complete residential desegregation.

The index of income dissimilarity was calculated from census data showing the distribution of black and white households across different income categories. Each index (Delta) represents the amount of inequality in the distribution of income between blacks and whites. For example an index of 20 indicates that in order to bring about equal distribution of income between the two groups, 20 percent of blacks or whites would need to be placed in different income categories.

\section{Procedure}

The 1970 and 1980 Census of Fopulation and

Housing were used in calculating the indexes of dissimilarity between black and white populations. Tracts with 400 or more blacks ("ghetta"), within the city of Portland contained a large concentration of the total black metropolitan population within them. The Delta was calculated separately for the "ghetto", Portland, Multnomah county (excluding Portland), Clackamas county, Washington county, Clark county, and SMSA respectively. Central city and suburban areas showed different racial compositions. Blacks were more concentrated in the central city than in 
suburbia. By using areal units, one can determine which areas show less segregation in comparison to the other areas in the SMSA. By comparing suburbs, central city, and ghetto--patterns of similarity and differences in the effect of change in income inequality upon residential segregation were detected. Tables I thru VII of appendix A show the indexes of residential segregation for 1970. Tables VIII thru XIV of appendix A show the Delta for 1980. These tables were used to compare and contrast the changes in residential segregation between 1970 and 1980.

In computing the indexes of dissimilarity for various income groups, Tables $p^{-4}$ and $p-6$ of the 1970 Census of Population and Housing were used. The tables describe the economic characteristics of the population for the "ghetto", the City of Portland, Multnomah County lexcluding City of Portland), Clackamas County, Washington County, Clark County, and the SMSA respectively (tables XV thru XXI, appendix A). For 1980, tables $p-13$ and $p-15$ of the census data were used in measuring the uneveness in the income distribution between the two groups. (tables XXII thru XXVIII, appendix A)

To examine the effects of socio-economic status on residential segregation, a sample of 281 blacks was available from the population of higher status blacks in the city of Portland. The data was obtained from Dr. William A. 
Little"s study, "Black leadership: Structure and Styles in Portland, Oregon". The objective of the study was to identify black leaders in Portland; develop a profile of the leaders; and to identify organizational bases of these leaders. For the purpose of this thesis (hypothesis 3 ) only 138 of the higher status blacks were analyzed, because the home addresses of the remaining 143 blacks were not available. Residential locations of the influential blacks were examined to determine whether or not their high status was accompanied by greater integration as opposed to greater segregation, when compared to the entire black population. In calculating the index of dissimilarity for this sample, the 1980 Census Tract Street Index was used to determine the census tract in which each influential black: lived. Delta was calculated separately for higher status blacks versus all other blacks, higher status blacks versus all whites, and all blacks versus all whites. 
CHAPTER IV

FINDINGS

In 1970 , blacks comprised 2.3 percent of the total population of the Portland Metropolitan Area. By 1980, the percentage had increased only 51 ightly to 2.8 percent. Thus, while the Portland Metropolitan Area was certainly not becoming more significantly black in its population composition thoughout the $1970^{\prime} \mathrm{s}$, there were noticeable and interesting changes occurring in the distribution of blacks in the Metropolitan area. As of 1980 there were over 33,000 blacks living in the Metropalitan area, over 10,000 more than 1 ived in the area in 1970. This $43.4 \%$ increase in the total black population was matched by a fairly equal increase in white population so that black-white composition didn't change very much. What did change was the distribution of black populations within the Metropolitan area, especially a visible and marked suburbanization of blacks.

Table 1 shows black population and percentage of black population for suburbs and the city of Portland. Tracts which had 400 or more blacks living in them are treated here as the "ghetto". In 1970, $76 \%$ of all blacks in the Metropolitan area were concentrated in the 13 tracts of the 
"ghetto", 17\% 1 ived in the balance of the central city of Portland (mostly in areas adjacent to the ghetto), and only $7 \%$ or 1 ess than 2000,1 ived in the suburbs. The same pattern of central city concentration was evident in 1980 , but with much lower density. The percentage of all blacks residing in the ghetto dropped from $76 \%$ to $64 \%$, even though the ghetto boundary expanded by four additional tracts.

The most important change occurred in suburbia. The rapid growth of suburban black population a $231 \%$ increase, far outstripped the 21 percent increase in the black. population in the ghetto and the 28 percent increase in the central city of Portland. By 1980, 17 percent of the black. population 1 ived in the suburbs compared to only 7 percent in 1970. Suburban Washington county had the greatest increase $(480.3 \%)$. Suburban Multnomah county, Clark, and Clackamas counties showed $264.3,195.6$, and 106.4 percentage points increase in their black populations.

The findings clearly show a dramatic process of black suburbanization in the Portland Metropolitan Area between 1970 and 1980, contrary to the national city-directed black migration. Employment opportunities and development of industry in suburbia helped in accelerating the suburbanization process of blacks in the metro area.

The median family income of blacks(table II) improved greatly in suburban Clackamas, Washington and Clark 
counties. The income position of blacks relative to whites declined slightly in the SMSA, but improved greatly in Clackamas county(table IV). Black population grew 1 arger mostly in the areas where noticeable gains occurred in the median family incomes. However, the median family income does not show the variance in the income distribution of blacks within different areas, but using tract analysis does show the relationship between income distribution and residential segregation across different areas.

Indexes of income segregation (table $V$ ) indicate that suburban Clark, Clackamas, and Washington counties were most affected by changes in income inequality. Wealthiest suburbs show biggest declines in segregation while the blue collar suburbs of east Multnomah county actually show an increase in income segregation.

A comparison of indices of income and residential segregation (table VII) demonstrates that decreases in income inequality were accompanied by reductions in residential segregation in the Portland Metropolitan Area between 1970 and 1980 . Those areas which experienced the greatest decline in income segregation generally tended to also hve the 1 argest decline in residential segregation. Pearsonian correlation(r) calculated across the seven subareas shown in table VIII indicates that change in income inequality was directly related to change in residential 
segregation $(r=.82)$. Hypothesis two was therefore confirmed. Figure I illustrates the clear pattern of relationship between change in income inequality and change in residential segregation.

Table IX depicts the deltas for influential blacks versus all other blacks, influential blacks versus all whites, and all blacks versus all whites ffor detailed calculations see tables $X X I X$ to $X X X I$ of appendi $X)$. This table shows that influential blacks were much less segregated from whites(delta=51) than were the rest of blacks(delta=71). However they were more similar in their residential pattern to blacks as a group (delta=35) than to whites (delta=51). Also, influential blacks were more segregated from other blacks (delta=35) than were blacks from whites in suburban areas (maximum suburban delta in ' 80 was 31). Of this sample of 138 blacks, about 59 percent $1 \mathrm{ived}$ in the ghetto areas, 26 percent in the balance of the city of Portland and 14 percent 1 ived in suburban areas. This is very similar to the distribution of all blacks in 1980 shown in table I. Of all blacks, 64 percent 1 ived in the ghetto, 19 percent in the balance of the city of Portland and 17 percent 1 ived in suburbia. Despite their status, a majority of these influential blacks still 1 ived in predominantly black areas. As Banfield argued earlier (1974:8)this could be the result of voluntary segregation on the part of this sample of influential 
blacks. My assumption is that these "leaders" had political interest in Portland's black community. In fact the research director, $\mathrm{Dr}$. Little, intended to identify these people as representatives of the black community. Therefore it was not a surprise to find these influentials more concentrated in the black community than in the white neighborhoods. Quite clearly, influential status for blacks was not a sufficient condition for their integration into white areas.

Two decades ago Grier and Grier (1965:17) asked whether Metropolitan areas could ever be desegregated as long as the mojority of blacks remain poor. They stated that the economic status of blacks posed a barrier to free dispersal of black population. Housing discrimination (Taeuber, Denton) and white attitudes(Myrdal) were also suggested as major barriers to desegregation of blacks. These data lend strong support to the argument that change in one variable, income inequality, is strongly associated with change in residential segregation. In suburban areas residential segregation was greatly reduced with the great reduction in income inequality. However, possession of influential status in the black community did not have the same recognizable impact upon desegregation.

The central city remained highly segregated throughout the nation. Low socio-economic status of blacks has been 
argued by McEntire(1960) and Silberman (1964) to be a determining factor in the segregation of blacks in central city. Housing discrimination and negative white attitudes may also play some role in keeping blacks segregated. According to Farley(1979:100), a department of housing and Urban development study conducted in 1977 discovered that in about one quarter of the instances where prospective black renters or buyers approached a realtor, they were subject to discrimination. Richard Taub(1984:8) suggested that middle class whites are somewhat more 1 ikely to accept middle class black neighbors than are working class whites to accept black neighbors of their own class. Comparison of the more heavily blue collar east Multnomah county with the white collar suburbs of Washington and Clackamas counties yields conclusions consistent with this arguement. The negative attitudes of whites are derived from the assumption that if blacks move into their neighborhoods the property values go down and the crime rate rises. According to Farley, fear of white hostility prevents blacks from seeking housing in white neighborhoods. Farley(1979:97) claimed that blacks overwhelmingly prefer mixed neighborhoods but are somewhat reluctant to move into a neighborhood where they would be the only black family, because they fear the hostile reactions of whites.

There is little doubt that residential segregation of blacks to some extent was shaped by the negative attitudes 
of whites toward blacks and by housing discrimination. But, as legal barriers have been lowered and blacks have become more acceptable to whites, improvement in the economic status of blacks has played an important role in desegregation of neighborhoods. 
TABLE I

BLACK POPULATION DISTRIBUTION IN 1970 AND 1980 SMSA

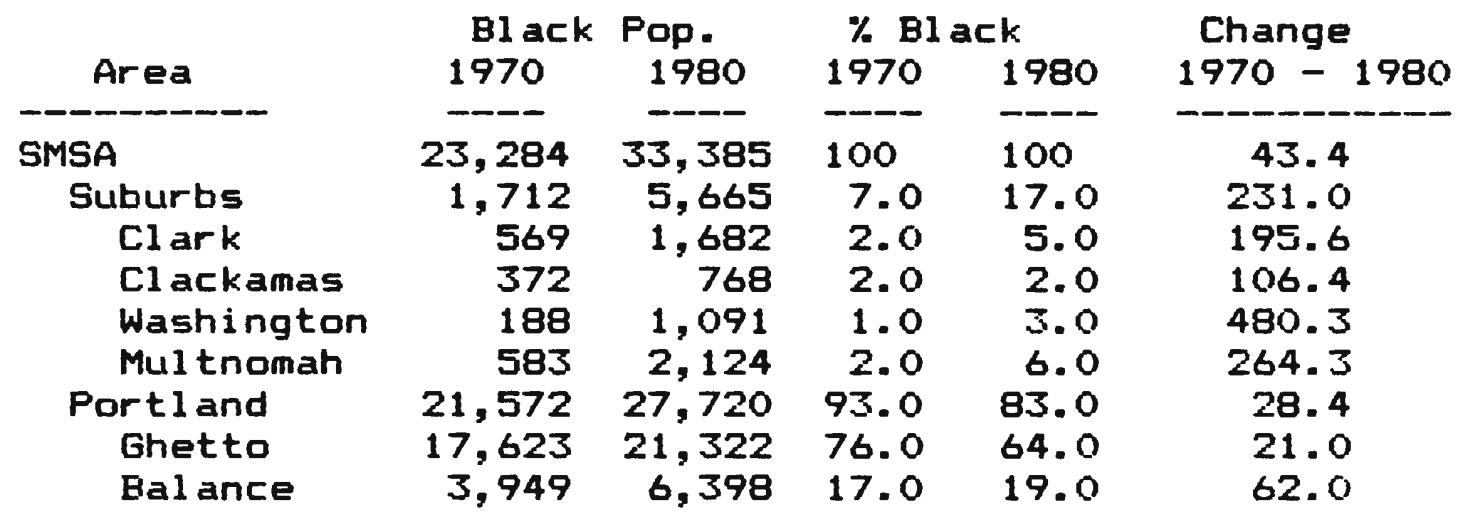

TABLE I I

BLACK MEDIAN FAMILY INCOME 1970 TO 1980

\begin{tabular}{lrc}
$\quad$ Area & 1970 & 1980 \\
\hline- SMSA & $-\$ 6,922$ & $\$ 11,707$ \\
Clark & $\$ 8,130$ & $\$ 15,554$ \\
Clackamas & $\$, 571$ & $\$ 26,705$ \\
Washington & $---*$ & $\$ 17,803$ \\
Multnomah & $\$ 10,250$ & $\$ 11,077$ \\
Portland & $\$ 6,844$ & $\$ 10,968$
\end{tabular}

* Census does not report the median family income of blacks in Washington county. 
TABLE I I I

WHITE MEDIAN FAMILY INCOME

1970 TO 1980

\begin{tabular}{lcc}
\multicolumn{1}{c}{ Area } & 1970 & 1980 \\
\hline SMSA & $-10,463$ & $\$ 18,703$ \\
Clark & $\$ 10,195$ & $\$ 19,051$ \\
Clackamas & $\$ 10,680$ & $\$ 21,208$ \\
Washington & $\$ 11,476$ & $\$ 21,766$ \\
Multnomah & $\$ 10,774$ & $\$ 16,389$ \\
Portland & $\$ \$, 794$ & $\$ 15,112$
\end{tabular}

TABLE IV

RATIO OF BLACK MEDIAN FAMILY INCOME

TO WHITE FAMILY INCOME

\begin{tabular}{lrr}
$\quad$ Area & 1970 & 1980 \\
\hline---- & --- & --- \\
SMSA & .66 & .62 \\
Clark & .80 & .82 \\
Clackamas & .90 & 1.26 \\
Washington & $? ? *$ & .82 \\
Multnomah & .95 & .67 \\
Portland & .70 & .72
\end{tabular}

* Data is not available for Washington county. 
TABLE $V$

INDEXES OF INCOME SEGREGATION

1970 AND 1980

\begin{tabular}{llll}
\multicolumn{1}{c}{ Area } & 1970 & 1980 & \% diff \\
\hline SMSA & -17.0 & -19.5 & -7.5 \\
Clark & 31.5 & 15.5 & -16.0 \\
Clackamas & 35.0 & 16.5 & -18.5 \\
Washington & 46.0 & 20.0 & -26.0 \\
Multnomah & 18.0 & 20.0 & +2.0 \\
Portland & 23.0 & 12.5 & -10.5 \\
"Ghetto" & 18.5 & 12.5 & -6.0
\end{tabular}

TAELE VI

INDEXES OF RESIDENTIAL SEGREGATION 1970 AND 1980

\begin{tabular}{llll}
\multicolumn{1}{c}{ Area } & 1970 & 1980 & diff \\
\hline SMSA & --- & -13 & - \\
Clark & 57.5 & 43.5 & -14.0 \\
Clackamas & $\mathbf{5 4 . 0}$ & 31.0 & -23.0 \\
Washington & 44.5 & 28.0 & -20.5 \\
Multnomah & 33.5 & 24.5 & -20.0 \\
Portland & 75.5 & 69.5 & -4.0 \\
"Ghetto" & 45.0 & 38.5 & -6.0 \\
& & &
\end{tabular}




\section{TABLE VII \\ INDEXES OF INCOME AND RESIDENTIAL SEGREGATION 1970 AND 1980}

\begin{tabular}{lllll}
\multicolumn{1}{c}{ Area } & Inc. & Res. & Inc. & Res. \\
\hline SMSA & --- & ---5 & -- & --1980 \\
Clark & 27.0 & 57.5 & 19.5 & 43.5 \\
Clackamas & 31.5 & 54.0 & 15.5 & 31.0 \\
Washington & 35.0 & 48.5 & 16.5 & 28.0 \\
Multnomah & 18.0 & 44.5 & 20.0 & 24.5 \\
Portland & 23.0 & 75.5 & 20.0 & 29.5 \\
"Ghetto" & 18.5 & 45.0 & 12.5 & 69.5 \\
& & & &
\end{tabular}

TABLE VIII

PERCENTAGE POINT DECLINES IN

SEGREGATION, 1970 - 1980

\begin{tabular}{lrr} 
Area & Income & Residential \\
\hline SMSA & -1.5 & 14.0 \\
Clark & 16.0 & 23.0 \\
Clackamas & 18.5 & 20.5 \\
Washington & 26.0 & 20.0 \\
Multnomah & -2.0 & 4.0 \\
Portland & 10.5 & 6.0 \\
Ghetto & 6.0 & 6.5 \\
\multicolumn{4}{c}{$r=.82$} \\
$c * 2=.67$
\end{tabular}


TABLE IX

INDICES OF RESIDENTIAL SEGREGATION

FOR TRACTS CONTAINING ANY INFLUENTIAL BLACKS

Influential Blacks

Influential

Bl acks

A1 1

Al 1

Blacks

Blacks Whites

All Blacks

0

35

35

51

51

0

71

Al I Whites

71

0 
FIGURE I

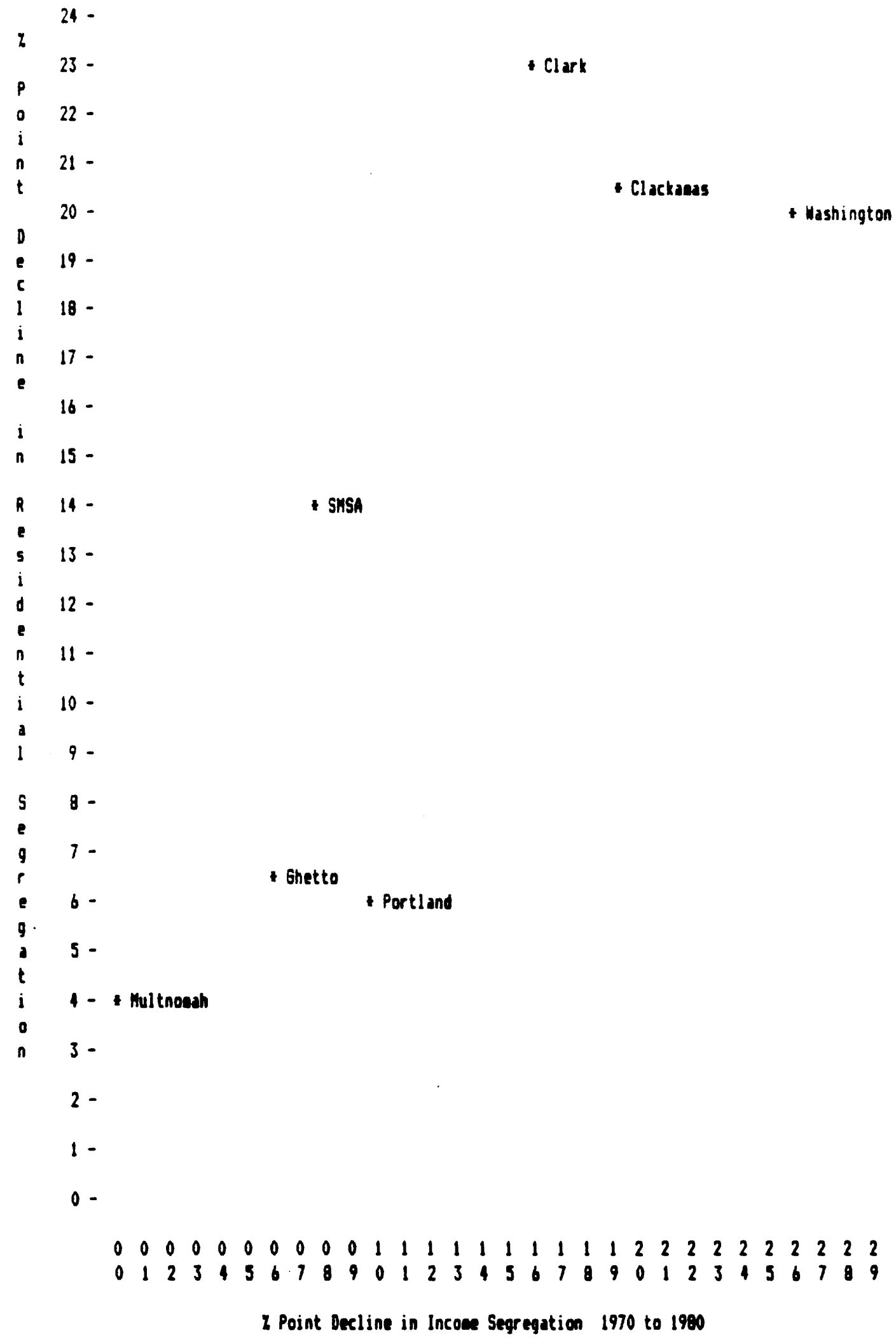


CHAPTER $V$

\section{DISCUSSION}

The civil rights movement of the $1960^{\circ} \mathrm{s}$ brought about some major changes in the status of blacks in America. The legal prohibition of discrimination in employment and housing expanded opportunities available to blacks. Blackwell and Hart argue (1982:3):

Blacks can legally rent and purchase housing in areas formerly off 1 imits, if they can afford such locales. Housing ordinances have made it possible for more blacks to move into formerly all-white urban and suburban enclaves. Wi thout question, the Omnibus housing bill or the Civil Rights Act of 1968 spurred the movement of some 800,000 blacks into suburbia between 1970 and 1977.

According to Farley, Bianchi, and Colasanto (1979:98), "There is ample documentation that blacks have made significant gains since 1960 in the economic and political spheres."

To what extent have the social and legal changes since the 1960's affected the black population in the city of Portland? Have income differentials decreased or increased between 1970 and 1980 and have segregation patterns changed any over the past decade? What is the relationship between the economic status of blacks and their patterns of residential segregation? The data suggest that there has 
been a major decrease in income inequality and in residential segregation between blacks and whites from 1970 thru 1980. In suburban areas, decreases in income inequality were accompanied by reduction in residential segregation. I, 1980, $17 \%$ of the black population in the metropolitan area 1 ived in suburbia compared to only $7 \%$ a decade earlier. The data indicate that suburban blacks were in higher income brackets and less segregated residentially as compared to the central city blacks. In the central city area and the ghetto blacks were in lower income catagories and more segregated residentially. Overall residential segregation decreased at a much faster rate in suburbia than the central city area. The central city experienced only a 14 percentage point decrease in segregation in the past forty years.

Data support the argument that economic status of blacks is a barrier to desegregating central city areas. According to Taub, Taylor, and Dunham (1984:12): "The shortage of blacks with adequate resources in cities is heightened by the fact that many of those with middle class incomes have followed their white counterparts to the suburbs." A similar suburbanization pattern occurred in the Portland Metropolitan Area between 1970 and 1980. Gain in economic status and reduction in income inequality resulted in rapid suburbanization of blacks. Residential segregation was greatly reduced with the settlement of upper and middle 
income blacks in suburbia. Comparison of central city and suburban areas clearly indicates the economic disadvantage of blacks in the central city was a major factor contributing to the high degree of residential segregation between blacks and whites. Housing discrimination and racial attitudes may still play some role in residential segregation of blacks but economic inequality remains the major obstacle in desegregation. 


\section{Bibliography}

Banfield, Edward C. 1974

The Unheavenly City Revisited

Little, Brown and Company, Boston

Bianchi, Farley and Spain 1982

"Racial inequalities in housing :

An examination of recent trends".

Demography, 19 (Feb): 37-51.

Bl ackwel 1, James E. 1975

The Black Community: Diversity and Unity

Dodd, Mead, and Co., Inc., New York, NY

Blackwel 1, James E. and Philip S. Hart 1982

Cities, Suburbs and Blacks

General Hal 1, Inc. New York

Bl auner, Robert 1972

Racial Oppression in America

Harper \& Row Publishers, New York

Clark, Kenneth B. 1965

Dark Ghetto; Dilemmas of Social Fower

Harper \& Row Publishers, New York

Denton, John H. 1967

Apartheid American Style

Diablo Press, Berkeley, Ca.

Drake, St. Clair and Horace Cayton 1962

Black Metropol is

Harper \& Row Publishers, New York

Duncan, Otis Dudley and Lieberson, Stanley 1959

"Ethnic segregation and assimilation".

American Journal of Sociology 64 (Jan): 364-374 
Farley, Bianchi, and Colasanto 1979

"Barriers to the racial integration

neighborhoods : The Detroit case".

Annals, AAPSS, 44 (Jan): 97-113

Farley, Reynolds 1970

"The changing distribution of negroes within metropolitan areas: The emergence of black suburbs".

American Journal of Sociology 75(Jan): 512-29

Farley, Reynolds 1977

"Trends in Racial Inequalities: Have the Gains of the "s disappeared in the "s ?"

American Socioloqical Review

42 (April) : 189-208.

Forman, Robert E. 1971

Black Ghettos, White Ghettos, and Slums

Prentice-Hal 1, Inc., New Jersey

Frey, William H. 1980

1980 "Black In-migration..., White flight, and

the changing economic base of the central city".

American Journal of Sociology

85 (July) : 1396-1417

Glazer, Nathan and Daniel Patrick Moynihan 1970

Beyond the Melting Pot

The M.I.T. Press, Mass

Grant, Joanne 1968

Bl ack Protest

Ballantine Books, NY.

Grier, Eunice and George Grier 1965

"Equality and beyond: Housing segregation in the great society".

IN The Neqro American pages: 525-554. edited by Talcott Parsons and Kenneth B. Clark. Houghton Mifflin Co. \& The American Accademy of Arts and Sciences, Boston. 
Grier, Eunice and George Grier 1964

"Obstacles to Desegregation in America"s Urban Areas".

Race $6(J u 1 y): 3-17$.

Hentoff, Nat 1965

The New Equality

The Viking Press, New York

Johnson, Charles S. 1943

Backgrounds to Patterns of Negro Segreqation Harper \& Row Publishers, New York

Johnson, James W. 1968

Black Manhattan

Arno Press and the New York Times, New York

Kain, John F. 1969

Race and Poverty

Prentice Hall, Inc. Englewood Cliffs, $\mathrm{NJ}$.

Kennedy, Louise V. 1968

The Nearo Peasant Turns Cityward

Amspress, Inc., New York

Lieberson, Stanley, and Donna K. Carter 1982

"A model for inferring the voluntary and involuntary causes of residential segregation".

Debography, 19(Nov): 511-525

Liebow, Elliot 1967

Tal1y's Corner

Little, Brown and Company, Boston

Massey, Douglas S. 1979

"Effects of socioeconomic factors on the residential segregation of blacks and Spanish Americans in the U.S. Urbanized areas". American Sociological Review 44 (Dec): 1015-22. 
McEntire, Davis 1960

Residence and Race

University of California press, Berkeley, CA.

Myrdal, Gunnar 1944

An American Dil emma

Harper \& Row Publishers, New York

Philpott, Thomas Lee 1978

The Slum and the Ghetto

Oxford University Fress, Inc.

Rainwater, Lee 1970

Behind Ghetto Walls

University of Chicago Press

Reich, Michael 1981

Racial Inequality

Princeton University Press, NJ.

Report of the National Advisory Commission

on Civil Disorders 1968

The New York Times Co., New York.

Reynolds, Graig A. 1981

"Employment and the income gap".

The Crisis 88 (may): 185-191

Rodgers, Harrel l R. 1975

Racism and Inequality

W.H. Freeman and Company, San Francisco, Ca.

Roof, Clark W. 1972

"Residential segregation of blacks and racial inequality in southern cities:

Toward a causal model ".

Social Problems 19(Winter): 392-407

Schwartz, Barry N., and Robert Disch 1970

White Raci sm

Dell Publishing Co., Inc, NY. 
Silberman, Charles E. 1964

Crisis in Black and White

Random House, Inc. NY.

Simkus, Albert A. 1978

"Residential segregation by accupation and race in urbanized areas, 1950-1970".

American Sociological Review 43(Feb): 81-93

Spear, All an H. 1967

Bl ack Chicago

University of Chicago press, ILL.

Tabb, William K. 1970

The Political Economy of the Black Ghetto

W.W. Nortan \& Co., Inc., New York

Taeuber, Karl E. 1968

"The effects of income redistribution on racial residential segregation".

Urban Affairs Quarterly 4(sept): 5-14

Taeuber, Karl E. and Alma F. Taeuber 1964

"The negero as an immigrant group; Recent trends in racial and ethnic segregation in Chicago". American Journal of Sociology 69(Jan): 372-82

Taeuber, Karl E. and Alma F. Taeuber 1972

Neqroes in Cities

Atheneum, New York

Taeuber, Karl E. 1975

"Racial Segregation : The Persisting Dilemma" Annals. AAPSS, vol 422, Nov

Taeuber, Karl E. 1965

"Residential segregation"

Scientific American Aug. page 9.

Taub, Taylor, and Dunham 1984

Paths of Nei ghborhood Change

University of Chicago Press 
Villemez, Wayne J. 1980

1980

"Race, class, and neighborhood: Differences in the residential return on individual resources". Social Forces 59 (Dec): 414-430

Weaver, Robert 1948

The Negro Ghetto

Harcourt, Brace and Co. , New York

Willhelm, Sidney M. 1970

Who Needs the Negro?

Schenkman Publishing Company, Inc. , Mass.

Woofter, T.J. 1928

Negro Problems in Cities

Arno Press Inc., New York

Wirth, Louis 1927

"The Ghetto"

American Journal of Sociology

vol. 33 (July) pg 57 


\section{APPENDIX}

\section{TABLE I}

\section{INDEX OF RESIDENTIAL SEGREGATION FOR}

TRACTS WITH 400 OR MORE BLACKS

$$
1970
$$

\begin{tabular}{lllllll} 
TRACT & $\begin{array}{l}\text { NUM } \\
\text { BLACK }\end{array}$ & BLACK & $\begin{array}{c}\text { NUM } \\
\text { WHITE }\end{array}$ & WHITE & DIFF \\
\hdashline 22.01 & 612 & 3 & 598 & 2 & 1 \\
23.01 & 1731 & 10 & 471 & 2 & 8 \\
23.02 & 563 & 3 & 663 & 2 & 1 \\
24.01 & 1616 & 9 & 2060 & 8 & 2 \\
32 & 1008 & 6 & 3460 & 13 & 7 \\
33.01 & 1853 & 11 & 1127 & 4 & 6 \\
33.02 & 1676 & 10 & 984 & 4 & 6 \\
34.01 & 2301 & 13 & 1181 & 4 & 9 \\
34.02 & 2403 & 14 & 424 & 2 & 12 \\
36.01 & 1678 & 10 & 2797 & 10 & 1 \\
36.02 & 897 & 5 & 5899 & 22 & 16 \\
37.02 & 490 & 3 & 2350 & 9 & 6 \\
39.01 & 795 & 5 & 5359 & 20 & 15 \\
TOTAL BLACKS : 17623 & TOTAL WHITES : 27373 \\
AVERAGE BLACKS $: 1356$ & AVERAGE WHITES:2106 \\
TOTAL TRACTS : 13 & DELTA : 45
\end{tabular}


TABLE I I

INDEX OF RESIDENTIAL SEGREGATION FOR PORTLAND

1970

\begin{tabular}{|c|c|c|c|c|c|}
\hline TRACT & $\begin{array}{c}\text { NUM } \\
\text { BLACK }\end{array}$ & $\begin{array}{c}\% \\
\text { BLACK }\end{array}$ & $\begin{array}{l}\text { NUM } \\
\text { WHITE }\end{array}$ & WHITE & DIFF \\
\hline 1 & 32 & 0 & 5949 & 2 & 2 \\
\hline 2 & 9 & 0 & 5631 & 2 & 2 \\
\hline 3.01 & 22 & 0 & 3107 & 1 & 1 \\
\hline 3.02 & 14 & 0 & 7688 & 2 & 2 \\
\hline 4.01 & 4 & 0 & 3647 & 1 & 1 \\
\hline 4.02 & 26 & 0 & 3372 & 1 & 1 \\
\hline 5.01 & 11 & 0 & 3597 & 1 & 1 \\
\hline 5.02 & 11 & 0 & 3841 & 1 & 1 \\
\hline 6.01 & 49 & 0 & 4468 & 1 & 1 \\
\hline 6.02 & 6 & 0 & 4084 & 1 & 1 \\
\hline 7.01 & 23 & 0 & 4234 & 1 & 1 \\
\hline 7.02 & 3 & 0 & 4493 & 1 & 1 \\
\hline 8.01 & 15 & 0 & 4852 & 1 & 1 \\
\hline 8.02 & 26 & 0 & 4468 & 1 & 1 \\
\hline 9.01 & 76 & 0 & 4378 & 1 & 1 \\
\hline 9.02 & 16 & 0 & 3408 & 1 & 1 \\
\hline 10 & 88 & 0 & 5731 & 2 & 1 \\
\hline 11.01 & 22 & 0 & 2182 & 1 & 1 \\
\hline 11.02 & 39 & 0 & 1601 & 0 & 0 \\
\hline 12.01 & 24 & 0 & 4589 & 1 & 1 \\
\hline 12.02 & 3 & 0 & 3287 & 1 & 1 \\
\hline 13.01 & 6 & 0 & 3828 & 1 & 1 \\
\hline 13.02 & 25 & 0 & 3211 & 1 & 1 \\
\hline 14 & 41 & 0 & 5054 & 1 & 1 \\
\hline 15 & 3 & 0 & 3773 & 1 & 1 \\
\hline 16.01 & 25 & 0 & 6006 & 2 & 2 \\
\hline 16.02 & 6 & 0 & 3861 & 1 & 1 \\
\hline 17.01 & 85 & 0 & 6612 & 2 & 1 \\
\hline 17.02 & 8 & 0 & 3709 & 1 & 1 \\
\hline 18.01 & 9 & 0 & 3745 & 1 & 1 \\
\hline 18.02 & 17 & 0 & 3079 & 1 & 1 \\
\hline 19 & 7 & 0 & 6304 & 2 & 2 \\
\hline 20 & 75 & 0 & 5555 & 2 & 1 \\
\hline 21 & 23 & 0 & 2394 & 1 & 1 \\
\hline 22.01 & 612 & 3 & 598 & 0 & 3 \\
\hline 22.02 & 251 & 1 & 205 & 0 & 1 \\
\hline 23.01 & 1731 & 8 & 471 & 0 & 8 \\
\hline 23.02 & 563 & 3 & 663 & 0 & 2 \\
\hline 24.01 & 1616 & 7 & 2060 & 1 & 7 \\
\hline 24.02 & 266 & & 2542 & 1 & 1 \\
\hline
\end{tabular}


TABLE II, CONT.

INDEX OF RESIDENTIAL SEGREGATION FOR PORTLAND

1970

\begin{tabular}{|c|c|c|c|c|c|}
\hline TRACT & $\begin{array}{c}\text { NUM } \\
\text { BLACK }\end{array}$ & BLACK & $\begin{array}{l}\text { NUM } \\
\text { WHITE }\end{array}$ & WHITE & DIFF \\
\hline 25.01 & 46 & 0 & 5589 & 2 & 1 \\
\hline 25.02 & 13 & 0 & 4039 & 1 & 1 \\
\hline 26 & 12 & 0 & 3127 & 1 & 1 \\
\hline 27.01 & 15 & 0 & 3648 & 1 & 1 \\
\hline 27.02 & 19 & 0 & 2646 & 1 & 1 \\
\hline 28.01 & 8 & 0 & 3484 & 1 & 1 \\
\hline 28.02 & 3 & 0 & 3369 & 1 & 1 \\
\hline 29.01 & 3 & 0 & 4206 & 1 & 1 \\
\hline 29.02 & 11 & 0 & 5946 & 2 & 2 \\
\hline 29.03 & 4 & 0 & 4197 & 1 & 1 \\
\hline 30 & 35 & 0 & 4961 & 1 & 1 \\
\hline 31 & 222 & 1 & 4638 & 1 & 0 \\
\hline 32 & 1008 & 5 & 3460 & 1 & 4 \\
\hline 33.01 & 1853 & 9 & 1127 & 0 & 8 \\
\hline 33.02 & 1676 & 8 & 984 & 0 & 7 \\
\hline 34.01 & 2301 & 11 & 1181 & 0 & 10 \\
\hline 34.02 & 2403 & 11 & 424 & 0 & 11 \\
\hline 35.01 & 285 & 1 & 3397 & 1 & 0 \\
\hline 35.02 & 376 & 2 & 2064 & 1 & 1 \\
\hline 36.01 & 1678 & 8 & 2797 & 1 & 7 \\
\hline 36.02 & 897 & 4 & 5899 & 2 & 2 \\
\hline 36.03 & 24 & 0 & 1863 & 1 & 0 \\
\hline 37.01 & 236 & 1 & 3830 & 1 & 0 \\
\hline 37.02 & 490 & 2 & 2350 & 1 & 2 \\
\hline 38.01 & 20 & 0 & 3162 & 1 & 1 \\
\hline 38.02 & 22 & 0 & 3023 & 1 & 1 \\
\hline 38.03 & 58 & 0 & 3745 & 1 & 1 \\
\hline 39.01 & 795 & 4 & 5359 & 2 & 2 \\
\hline 39.02 & 18 & 0 & 3256 & 1 & 1 \\
\hline 40.01 & 343 & 2 & 5365 & 2 & 0 \\
\hline 40.02 & 54 & 0 & 5146 & 1 & 1 \\
\hline 40.99 & 0 & 0 & 21 & 0 & 0 \\
\hline 41.01 & 27 & 0 & 4943 & 1 & 1 \\
\hline 41.02 & 24 & 0 & 4714 & 1 & 1 \\
\hline 41.99 & 13 & 0 & 126 & 0 & 0 \\
\hline 42 & 24 & 0 & 2889 & 1 & 1 \\
\hline 43 & 1 & 0 & 865 & 0 & 0 \\
\hline 44 & 0 & 0 & 70 & 0 & 0 \\
\hline 44.99 & 0 & 0 & 8 & 0 & 0 \\
\hline 45 & 31 & 0 & 1978 & 1 & 0 \\
\hline
\end{tabular}


TABLE II, CONT.

INDEX OF RESIDENTIAL SEGREGATION FOR PORTLAND

1970

\begin{tabular}{|c|c|c|c|c|c|}
\hline TRACT & $\begin{array}{l}\text { NUM } \\
\text { BLACK }\end{array}$ & $\begin{array}{c}\% \\
\text { BLACK }\end{array}$ & $\begin{array}{c}\text { NUM } \\
\text { WHITE }\end{array}$ & $\begin{array}{c}\% \\
\text { WHITE }\end{array}$ & DIFF \\
\hline 46.01 & 2 & 0 & 2727 & 1 & 1 \\
\hline 46.02 & 7 & 0 & 2007 & 1 & 1 \\
\hline 47 & 15 & 0 & 4015 & 1 & 1 \\
\hline 48 & 15 & 0 & 3171 & 1 & 1 \\
\hline 49 & 38 & 0 & 3207 & 1 & 1 \\
\hline 50 & 15 & 0 & 739 & 0 & 0 \\
\hline 51 & 125 & 1 & 1176 & 0 & 0 \\
\hline 52 & 17 & 0 & 3424 & 1 & 1 \\
\hline 53 & 28 & 0 & 1938 & 1 & 0 \\
\hline 54 & 31 & 0 & 817 & 0 & 0 \\
\hline 55 & 13 & 0 & 1182 & 0 & 0 \\
\hline 56 & 51 & 0 & 2566 & 1 & 0 \\
\hline 57 & 17 & 0 & 975 & 0 & 0 \\
\hline 58 & 76 & 0 & 5476 & 2 & 1 \\
\hline 59 & 62 & 0 & 2599 & 1 & 0 \\
\hline 60.01 & 4 & 0 & 922 & 0 & 0 \\
\hline 60.02 & 2 & 0 & 2321 & 1 & 1 \\
\hline 61 & 1 & 0 & 1974 & 1 & 1 \\
\hline 62 & 1 & 0 & 2789 & 1 & 1 \\
\hline 63 & 27 & 0 & 2844 & 1 & 1 \\
\hline 64 & 1 & 0 & 1435 & 0 & 0 \\
\hline 65.01 & 1 & 0 & 1638 & 0 & 0 \\
\hline 65.02 & 8 & 0 & 2106 & 1 & 1 \\
\hline 66.01 & 2 & 0 & 1868 & 1 & 1 \\
\hline 66.02 & 7 & 0 & 3995 & 1 & 1 \\
\hline 67.01 & 10 & 0 & 2568 & 1 & 1 \\
\hline 67.02 & 10 & 0 & 4484 & 1 & 1 \\
\hline 68.01 & 3 & 0 & 1257 & 0 & 0 \\
\hline 68.02 & 11 & 0 & 2653 & 1 & 1 \\
\hline 69 & 0 & 0 & 992 & 0 & 0 \\
\hline 70 & 3 & 0 & 256 & 0 & 0 \\
\hline 72 & 4 & 0 & 580 & 0 & 0 \\
\hline 73 & 2 & 0 & 279 & 0 & 0 \\
\hline 74 & 11 & 0 & 853 & 0 & 0 \\
\hline 75 & 13 & 0 & 942 & 0 & 0 \\
\hline 82.01 & 0 & 0 & 57 & 0 & 0 \\
\hline 83 & 1 & 0 & 1072 & 0 & 0 \\
\hline 85 & 0 & 0 & 584 & 0 & 0 \\
\hline 87 & 2 & 0 & 140 & 0 & 0 \\
\hline 88 & 0 & 0 & 50 & 0 & 0 \\
\hline
\end{tabular}


TABLE I I, CONT.

INDEX OF RESIDENTIAL SEGREGATION FOR PORTLAND

1970

\begin{tabular}{lllllll} 
& NUM & \% & \multicolumn{1}{c}{ NUM } & $\%$ & \\
TRACT & BLACK & BLACK & WHITE & WHITE & DIFF \\
\hline 89 & 0 & 0 & 1176 & 0 & 0 \\
91 & 0 & 0 & 49 & 0 & 0
\end{tabular}

TOTAL BLACKS : 21572 TOTAL WHITES : 352076

AVERAGE BLACKS : 177 AVERAGE WHITES : 2886

TOTAL TRACTS : 122 DELTA : 75.5 
TABLE II I

INDEX OF RESIDENTIAL SEGREGATION FOR MULTNOMAH COUNTY

1970

\begin{tabular}{|c|c|c|c|c|c|}
\hline TRACT & $\begin{array}{c}\text { NUM } \\
\text { BLACK }\end{array}$ & BLACK & $\begin{array}{l}\text { NUM } \\
\text { WHITE }\end{array}$ & $\begin{array}{c}\% \\
\text { WHITE }\end{array}$ & DIFF \\
\hline 6.01 & 0 & 0 & 462 & 0 & 0 \\
\hline 6.02 & 0 & 0 & 149 & 0 & 0 \\
\hline 16.02 & 4 & 1 & 668 & 0 & 0 \\
\hline 17.02 & 3 & 1 & 187 & 0 & 0 \\
\hline 29.01 & 1 & 0 & 683 & 0 & 0 \\
\hline 29.03 & 0 & 0 & 281 & 0 & 0 \\
\hline 41.01 & 0 & 0 & 32 & 0 & 0 \\
\hline 41.99 & 3 & 1 & 38 & 0 & 0 \\
\hline 43 & 11 & 2 & 261 & 0 & 2 \\
\hline 63 & 5 & 1 & 1526 & 1 & 0 \\
\hline 64 & 6 & 1 & 3286 & 2 & 1 \\
\hline 65.01 & 0 & 0 & 1649 & 1 & 1 \\
\hline 65.02 & 11 & 2 & 926 & 1 & 1 \\
\hline 68.01 & 1 & 0 & 646 & 0 & 0 \\
\hline 68.02 & 0 & 0 & 46 & 0 & 0 \\
\hline 69 & 4 & 1 & 1291 & 1 & 0 \\
\hline 70 & 19 & 3 & 1634 & 1 & 2 \\
\hline 71 & 6 & 1 & 1740 & 1 & 0 \\
\hline 72 & 9 & 2 & 1986 & 1 & 0 \\
\hline 73 & 7 & 1 & 1758 & 1 & 0 \\
\hline 74 & 14 & 2 & 1491 & 1 & 2 \\
\hline 75 & 16 & 3 & 3208 & 2 & 1 \\
\hline 76 & 14 & 2 & 3313 & 2 & 0 \\
\hline 77 & 10 & 2 & 2083 & 1 & 1 \\
\hline 78 & 79 & 14 & 2273 & 1 & 12 \\
\hline 79 & 8 & 1 & 3872 & 2 & 1 \\
\hline 80.01 & 13 & 2 & 3431 & 2 & 0 \\
\hline 80.02 & 3 & 1 & 3126 & 2 & 1 \\
\hline 81 & 13 & 2 & 6509 & 4 & 2 \\
\hline 82.01 & 31 & 5 & 2544 & 1 & 4 \\
\hline 82.02 & 16 & 3 & 5112 & 3 & 0 \\
\hline 83 & 4 & 1 & 5316 & 3 & 2 \\
\hline 84 & 8 & 1 & 2616 & 2 & 0 \\
\hline 85 & 12 & 2 & 3060 & 2 & 0 \\
\hline 86 & 2 & 0 & 3201 & 2 & 2 \\
\hline 87 & 17 & 3 & 3959 & 2 & 1 \\
\hline 88 & 22 & 4 & 3674 & 2 & 2 \\
\hline 89 & 4 & 1 & 2981 & 2 & 1 \\
\hline 90 & 16 & 3 & 4354 & 3 & 0 \\
\hline 91 & 15 & 3 & 4977 & 3 & 0 \\
\hline
\end{tabular}


TABLE II I, CONT.

INDEX OF RESIDENTIAL SEGREGATION FOR MULTNOMAH COUNTY

1970

\begin{tabular}{llllll} 
TRACT & $\begin{array}{l}\text { NLAM } \\
\text { BLACK }\end{array}$ & $\begin{array}{c}\% \\
\text { BLACK }\end{array}$ & $\begin{array}{c}\text { NUM } \\
\text { WHITE }\end{array}$ & WHITE & DIFF \\
\hline 92.01 & 4 & 1 & 5311 & 3 & 2 \\
92.02 & 5 & 1 & 3917 & 2 & 1 \\
93 & 21 & 4 & 6480 & 4 & 0 \\
94 & 29 & 5 & 5891 & 3 & 2 \\
95 & 20 & 3 & 4091 & 2 & 1 \\
96.01 & 21 & 4 & 5200 & 3 & 1 \\
96.02 & 0 & 0 & 5010 & 3 & 3 \\
97.01 & 0 & 0 & 4206 & 2 & 2 \\
97.02 & 8 & 1 & 6469 & 4 & 2 \\
98.01 & 11 & 2 & 2109 & 1 & 1 \\
98.02 & 7 & 1 & 6155 & 4 & 2 \\
99 & 2 & 0 & 3597 & 2 & 2 \\
100 & 6 & 1 & 4611 & 3 & 2 \\
101 & 2 & 0 & 3470 & 2 & 2 \\
102 & 1 & 0 & 915 & 1 & 0 \\
103 & 21 & 4 & 3258 & 2 & 2 \\
104.01 & 7 & 1 & 5230 & 3 & 2 \\
104.02 & 7 & 1 & 2473 & 1 & 0 \\
105 & 4 & 1 & 2704 & 2 & 1
\end{tabular}

TOTAL BLACKS : 583 TOTAL WHITES : 171446

AVERAGE BLACKS : 10 AVERAGE WHITES : 2906 TOTAL TRACTS : 59 DELTA : 33.5 
TABLE IV

INDEX OF RESIDENTIAL SEGREGATION FOR CLACKAMAS COUNTY

1970

\begin{tabular}{|c|c|c|c|c|c|}
\hline TRACT & $\begin{array}{l}\text { NUM } \\
\text { BLACK }\end{array}$ & $\begin{array}{c}\% \\
\text { BLACK }\end{array}$ & $\begin{array}{c}\text { NUM } \\
\text { WHITE }\end{array}$ & $\begin{array}{c}\% \\
\text { WHITE }\end{array}$ & DIFF \\
\hline 201 & 7 & 2 & 3693 & 2 & 0 \\
\hline 202 & 6 & 2 & 4803 & 3 & 1 \\
\hline 203 & 0 & 0 & 3852 & 2 & 2 \\
\hline 204 & 7 & 2 & 7757 & 5 & 3 \\
\hline 205 & 11 & 3 & 6253 & 4 & 1 \\
\hline 206 & 2 & 1 & 3097 & 2 & 1 \\
\hline 207 & 3 & 1 & 1486 & 1 & 0 \\
\hline 208 & 3 & 1 & 3551 & 2 & 1 \\
\hline 209 & 4 & 1 & 4186 & 3 & 1 \\
\hline 210 & 5 & 1 & 4578 & 3 & 1 \\
\hline 211 & 2 & 1 & 4534 & 3 & 2 \\
\hline 212 & 1 & 0 & 3124 & 2 & 2 \\
\hline 213 & 8 & 2 & 4547 & 3 & 1 \\
\hline 214 & 10 & 3 & 3252 & 2 & 1 \\
\hline 215 & 1 & 0 & 2662 & 2 & 1 \\
\hline 216 & 10 & 3 & 6857 & 4 & 1 \\
\hline 217 & 3 & 1 & 4042 & 2 & 2 \\
\hline 218 & 0 & 0 & 5206 & 3 & 3 \\
\hline 219 & 1 & 0 & 2432 & 1 & 1 \\
\hline 220 & 6 & 2 & 4043 & 2 & 1 \\
\hline 221 & 6 & 2 & 6743 & 4 & 2 \\
\hline 222 & 12 & 3 & 5466 & 3 & 0 \\
\hline 223 & 6 & 2 & 4100 & 2 & 1 \\
\hline 224 & 2 & 1 & 4085 & 2 & 2 \\
\hline 225 & 0 & 0 & 4409 & 3 & 3 \\
\hline 226 & 0 & 0 & 2921 & 2 & 2 \\
\hline 227 & 36 & 10 & 4075 & 2 & 7 \\
\hline 228 & 1 & 0 & 2345 & 1 & 1 \\
\hline 229 & 10 & 3 & 3778 & 2 & 0 \\
\hline 230 & 9 & 2 & 2395 & 1 & 1 \\
\hline 231 & 11 & 3 & 2498 & 2 & 1 \\
\hline 232 & 16 & 4 & 3319 & 2 & 2 \\
\hline 233 & 4 & 1 & 3264 & 2 & 1 \\
\hline 234 & 1 & 0 & 5143 & 3 & 3 \\
\hline 235 & 16 & 4 & 2698 & 2 & 3 \\
\hline 236 & 0 & 0 & 1761 & 1 & 1 \\
\hline 237 & 8 & 2 & 2648 & 2 & 1 \\
\hline 238 & 1 & 0 & 4190 & 3 & 2 \\
\hline 239 & 0 & 0 & 3431 & 2 & 2 \\
\hline 240 & 0 & 0 & 1275 & 1 & 1 \\
\hline
\end{tabular}


TABLE IV, CONT.

$$
\begin{gathered}
\text { INDEX OF RESIDENTIAL SEGREGATION FOR } \\
\text { CLACKAMAS COUNTY } \\
1970
\end{gathered}
$$

\begin{tabular}{lllllll} 
TRACT & $\begin{array}{l}\text { NUM } \\
\text { BLACK }\end{array}$ & BLACK & $\begin{array}{l}\text { NHI } \\
\text { WHE }\end{array}$ & WHITE & DIFF \\
\hline 241 & 1 & 0 & 2503 & 2 & 1 \\
242 & 134 & 36 & 3266 & 2 & 34 \\
243 & 8 & 2 & 3920 & 2 & 0
\end{tabular}

TOTAL BLACKS : 372 TOTAL WHITES : 164188

AVERAGE BLACKS : 9 AVERAGE WHITES : 3818

TOTAL TRACTS : 43 DELTA : 48.5 
TABLE $V$

INDEX OF RESIDENTIAL SEGREGATION FOR WASHINGTON COUNTY

1970

\begin{tabular}{|c|c|c|c|c|c|}
\hline TRACT & $\begin{array}{c}\text { NUM } \\
\text { BLACK }\end{array}$ & BLACK & $\begin{array}{l}\text { NUM } \\
\text { WHI TE }\end{array}$ & $\begin{array}{c}\% \\
\text { WHITE }\end{array}$ & DIFF \\
\hline 301 & 0 & 0 & 4556 & 3 & 3 \\
\hline 302 & 2 & 1 & 6080 & 4 & 3 \\
\hline 303 & 3 & 2 & 4937 & 3 & 2 \\
\hline 304 & 4 & 2 & 6624 & 4 & 2 \\
\hline 305 & 5 & 3 & 5550 & 4 & 1 \\
\hline 306 & 1 & 1 & 3210 & 2 & 2 \\
\hline 307 & 0 & 0 & 1716 & 1 & 1 \\
\hline 309 & 8 & 4 & 4521 & 3 & 1 \\
\hline 309 & 1 & 1 & 3349 & 2 & 2 \\
\hline 310 & 6 & 3 & 7761 & 5 & 2 \\
\hline 311 & 1 & 1 & 2334 & 1 & 1 \\
\hline 312 & 1 & 1 & 4417 & 3 & 2 \\
\hline 313 & 13 & 7 & 4219 & 3 & 4 \\
\hline 314.01 & 17 & 9 & 10571 & 7 & 2 \\
\hline 314.02 & 9 & 5 & 1059 & 1 & 4 \\
\hline 315 & 7 & 4 & 9140 & 6 & 2 \\
\hline 316 & 4 & 2 & 5162 & 3 & 1 \\
\hline 317 & 1 & 1 & 4859 & 3 & 3 \\
\hline 318 & 13 & 7 & 3093 & 2 & 5 \\
\hline 319 & 2 & 1 & 7379 & 5 & 4 \\
\hline 320 & 0 & 0 & 1817 & 1 & 1 \\
\hline 321 & 2 & 1 & 3407 & 2 & 1 \\
\hline 322 & 1 & 1 & 2187 & 1 & 1 \\
\hline 323 & 3 & 2 & 1930 & 1 & 0 \\
\hline 324 & 4 & 2 & 7291 & 5 & 3 \\
\hline 325 & 0 & 0 & 3566 & 2 & 2 \\
\hline 326 & 9 & 5 & 8389 & 5 & 1 \\
\hline 327 & 0 & 0 & 2656 & 2 & 2 \\
\hline 328 & 0 & 0 & 1465 & 1 & 1 \\
\hline 329 & 3 & 2 & 3922 & 3 & 1 \\
\hline 330 & 0 & 0 & 4019 & 3 & 3 \\
\hline 331 & 6 & 3 & 4244 & 3 & 0 \\
\hline 332 & 47 & 25 & 2507 & 2 & 23 \\
\hline 333 & 8 & 4 & 3519 & 2 & 2 \\
\hline 334 & 3 & 2 & 1499 & 1 & 1 \\
\hline 335 & 2 & 1 & 1614 & 1 & 0 \\
\hline 336 & 2 & 1 & 1613 & 1 & 0 \\
\hline
\end{tabular}


TABLE $V$, CONT.

INDEX OF RESIDENTIAL SEGREGATION FOR WASHINGTON COUNTY

1970

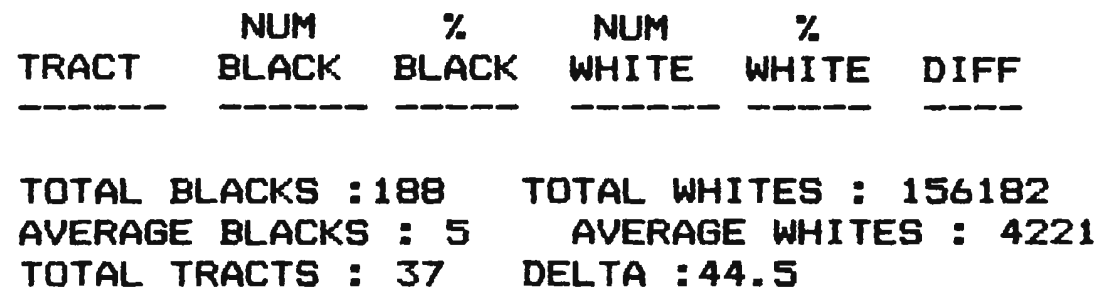


TABLE VI

INDEX OF RESIDENTIAL SEGREGATION FOR

CLARK COUNTY

$$
1970
$$

\begin{tabular}{|c|c|c|c|c|c|}
\hline TRACT & $\begin{array}{c}\text { NUM } \\
\text { BLACK }\end{array}$ & $\%$ & $\begin{array}{l}\text { NUM } \\
\text { WHI TE }\end{array}$ & $\begin{array}{c}\% \\
\text { WHITE }\end{array}$ & DIFF \\
\hline 401 & 8 & 1 & 2557 & 2 & 1 \\
\hline 402 & 3 & 1 & 3436 & 3 & 2 \\
\hline 403 & 0 & 0 & 2620 & 2 & 2 \\
\hline 404 & 11 & 2 & 7474 & 6 & 4 \\
\hline 405.01 & 0 & 0 & 2043 & 2 & 2 \\
\hline 405.02 & 0 & 0 & 1926 & 2 & 2 \\
\hline 405.03 & 2 & 0 & 4399 & 3 & 3 \\
\hline 406 & 8 & 1 & 4095 & 3 & 2 \\
\hline 407 & 10 & 2 & 4911 & 4 & 2 \\
\hline 408 & 2 & 0 & 5774 & 5 & 4 \\
\hline 409 & 0 & 0 & 6482 & 5 & 5 \\
\hline 410.01 & 6 & 1 & 9481 & 7 & 6 \\
\hline 410.02 & 6 & 1 & 3749 & 3 & 2 \\
\hline 411.01 & 8 & 1 & 5577 & 4 & 3 \\
\hline 411.02 & 0 & 0 & 3520 & 3 & 3 \\
\hline 412 & 20 & 4 & 9638 & 8 & 4 \\
\hline 413 & 25 & 4 & 5641 & 4 & 0 \\
\hline 414 & 1 & 0 & 3082 & 2 & 2 \\
\hline 415 & 13 & 2 & 2523 & 2 & 0 \\
\hline 416 & 0 & 0 & 1652 & 1 & 1 \\
\hline 417 & 27 & 5 & 2523 & 2 & 3 \\
\hline 418 & 21 & 4 & 3649 & 3 & 1 \\
\hline 419 & 8 & 1 & 2242 & 2 & 0 \\
\hline 420 & 1 & 0 & 1760 & 1 & 1 \\
\hline 421 & 4 & 1 & 2257 & 2 & 1 \\
\hline 422 & 0 & 0 & 1586 & 1 & 1 \\
\hline 423 & 51 & 9 & 2699 & 2 & 7 \\
\hline 424 & 10 & 2 & 845 & 1 & 1 \\
\hline 425 & 4 & 1 & 1543 & 1 & 1 \\
\hline 426 & 37 & 7 & 3470 & 3 & 4 \\
\hline 426.99 & 8 & 1 & 47 & 0 & 1 \\
\hline 427 & 32 & 6 & 1742 & 1 & 4 \\
\hline 428 & 121 & 21 & 3123 & 2 & 19 \\
\hline 429 & 12 & 2 & 2165 & 2 & 0 \\
\hline 430 & 41 & 7 & 2250 & 2 & 5 \\
\hline 431 & 69 & 12 & 4484 & 4 & 9 \\
\hline
\end{tabular}

TOTAL BLACKS :569 TOTAL WHITES : 126965 AVERAGE BLACKS : 16 AVERAGE WHITES : 3527 TOTAL TRACTS : 36 DELTA : 54 
TABLE VII

INDEX OF RESIDENTIAL SEGREGATION FOR TRACTS WITH 400 OR MORE BLACKS 1980

\begin{tabular}{lllllll} 
& NUM & $\%$ & NUM & $\%$ & \\
TRACT & BLACK & BLACK & WHITE & WHITE & D IFF \\
\hline 23.01 & 1446 & 7 & 708 & 2 & 5 \\
24.01 & 1197 & 6 & 1825 & 5 & 0 \\
31 & 687 & 3 & 3876 & 12 & 8 \\
32 & 1596 & 7 & 2447 & 7 & 0 \\
33.01 & 1802 & 8 & 810 & 2 & 6 \\
33.02 & 1883 & 9 & 814 & 2 & 6 \\
34.01 & 2300 & 11 & 849 & 3 & 8 \\
34.02 & 2167 & 10 & 374 & 1 & 9 \\
35.01 & 534 & 3 & 2644 & 8 & 5 \\
36.01 & 2063 & 10 & 1814 & 5 & 4 \\
36.02 & 2176 & 10 & 3735 & 11 & 1 \\
37.01 & 758 & 4 & 2815 & 8 & 5 \\
37.02 & 842 & 4 & 1644 & 5 & 1 \\
39.01 & 910 & 4 & 4583 & 14 & 9 \\
40.01 & 961 & 5 & 4749 & 14 & 10
\end{tabular}

TOTAL BLACKS : 21322 TOTAL WHITES : 33687

AVERAGE BLACKS : 1421 AVERAGE WHITES : 2246 TOTAL TRACTS : 15 DELTA : 38.5 
TABLE VIII

INDEX OF RESIDENTIAL SEGREGATION FOR PORTLAND

1980

\begin{tabular}{|c|c|c|c|c|c|}
\hline TRACT & $\begin{array}{c}\text { NUM } \\
\text { BLACK }\end{array}$ & $\begin{array}{c}\% \\
\text { BLACK }\end{array}$ & $\begin{array}{c}\text { NUM } \\
\text { WHITE }\end{array}$ & WHITE & DIFF \\
\hline 1 & 46 & 0 & 4996 & 2 & 1 \\
\hline 2 & 46 & 0 & 5197 & 2 & 1 \\
\hline 3.01 & 70 & 0 & 4161 & 1 & 1 \\
\hline 3.02 & 18 & 0 & 6465 & 2 & 2 \\
\hline 4.01 & 18 & 0 & 3202 & 1 & 1 \\
\hline 4.02 & 21 & 0 & 3155 & 1 & 1 \\
\hline 5.01 & 18 & 0 & 3247 & 1 & 1 \\
\hline 5.02 & 29 & 0 & 3579 & 1 & 1 \\
\hline 6.01 & 42 & 0 & 3762 & 1 & 1 \\
\hline 6.02 & 28 & 0 & 3837 & 1 & 1 \\
\hline 7.01 & 56 & 0 & 3960 & 1 & 1 \\
\hline 7.02 & 24 & 0 & 3951 & 1 & 1 \\
\hline 8.01 & 52 & 0 & 4084 & 1 & 1 \\
\hline 8. 02 & 54 & 0 & 4003 & 1 & 1 \\
\hline 9.01 & 78 & 0 & 3574 & 1 & 1 \\
\hline 9.02 & 87 & 0 & 3578 & 1 & 1 \\
\hline 10 & 174 & 1 & 4928 & 2 & 1 \\
\hline 11.01 & 36 & 0 & 1483 & 0 & 0 \\
\hline 11.02 & 44 & 0 & 1229 & 0 & 0 \\
\hline 12.01 & 140 & 1 & 3878 & 1 & 1 \\
\hline 12.02 & 27 & 0 & 2972 & 1 & 1 \\
\hline 13.01 & 59 & 0 & 3314 & 1 & 1 \\
\hline 13.02 & 34 & 0 & 2692 & 1 & 1 \\
\hline 14 & 69 & 0 & 4340 & 1 & 1 \\
\hline 15 & 33 & 0 & 3284 & 1 & 1 \\
\hline 16.01 & 64 & 0 & 5036 & 2 & 1 \\
\hline 16.02 & 17 & 0 & 2781 & 1 & 1 \\
\hline 17.01 & 94 & 0 & 5708 & 2 & 1 \\
\hline 17.02 & 46 & 0 & 3449 & 1 & 1 \\
\hline 18.01 & 45 & 0 & 3269 & 1 & 1 \\
\hline 18.02 & 26 & 0 & 2922 & 1 & 1 \\
\hline 19 & 43 & 0 & 5054 & 2 & 1 \\
\hline 20 & 188 & 1 & 4787 & 2 & 1 \\
\hline 21 & 65 & 0 & 1832 & 1 & 0 \\
\hline 22.01 & 145 & 1 & 177 & 0 & 0 \\
\hline 22.02 & 78 & 0 & 94 & 0 & 0 \\
\hline 23.01 & 1446 & 5 & 708 & 0 & 5 \\
\hline 23.02 & 308 & 1 & 662 & 0 & 1 \\
\hline 24.01 & 1197 & 4 & 1825 & 1 & 4 \\
\hline 24.02 & 264 & 1 & 2327 & 1 & 0 \\
\hline
\end{tabular}


TABLE VIII, CONT.

INDEX OF RESIDENTIAL SEGREGATION FOR PORTLAND

1980

\begin{tabular}{|c|c|c|c|c|c|}
\hline TRACT & $\begin{array}{c}\text { NUM } \\
\text { BLACK }\end{array}$ & BLACK & $\begin{array}{l}\text { NUM } \\
\text { WHITE }\end{array}$ & WHITE & DIFF \\
\hline 25.01 & 147 & 1 & 4650 & 1 & 1 \\
\hline 25.02 & 175 & 1 & 3447 & 1 & 0 \\
\hline 26 & 34 & 0 & 2640 & 1 & 1 \\
\hline 27.01 & 31 & 0 & 3076 & 1 & 1 \\
\hline 27.02 & 35 & 0 & 2358 & 1 & 1 \\
\hline 28.01 & 24 & 0 & 2907 & 1 & 1 \\
\hline 28.02 & 39 & 0 & 2697 & 1 & 1 \\
\hline 29.01 & 23 & 0 & 3657 & 1 & 1 \\
\hline 29.02 & 44 & 0 & 4848 & 2 & 1 \\
\hline 29.03 & 42 & 0 & 3804 & 1 & 1 \\
\hline 30 & 175 & 1 & 4015 & 1 & 1 \\
\hline 31 & 687 & 2 & 3876 & 1 & 1 \\
\hline 32 & 1596 & 6 & 2447 & 1 & 5 \\
\hline 33.01 & 1802 & 7 & 810 & 0 & 6 \\
\hline 33.02 & 1883 & 7 & 814 & 0 & 7 \\
\hline 34.01 & 2300 & 8 & 849 & 0 & 8 \\
\hline 34.02 & 2167 & 8 & 374 & 0 & 8 \\
\hline 35.01 & 534 & 2 & 2644 & 1 & 1 \\
\hline 35.02 & 301 & 1 & 1608 & 1 & 1 \\
\hline 36.01 & 2063 & 7 & 1814 & 1 & 7 \\
\hline 36.02 & 2176 & 8 & 3735 & 1 & 7 \\
\hline 36.03 & 248 & 1 & 1357 & 0 & 0 \\
\hline 37.01 & 758 & 3 & 2815 & 1 & 2 \\
\hline 37.02 & 842 & 3 & 1644 & 1 & 3 \\
\hline 38.01 & 101 & 0 & 2312 & 1 & 0 \\
\hline 38.02 & 137 & 0 & 2587 & 1 & 0 \\
\hline 38.03 & 319 & 1 & 3444 & 1 & 0 \\
\hline 39.01 & 910 & 3 & 4583 & 1 & 2 \\
\hline 39.02 & 51 & 0 & 2979 & 1 & 1 \\
\hline 40.01 & 961 & 3 & 4749 & 2 & 2 \\
\hline 40.02 & 68 & 0 & 4454 & 1 & 1 \\
\hline 40.99 & 0 & 0 & 0 & 0 & 0 \\
\hline 41.01 & 161 & 1 & 5048 & 2 & 1 \\
\hline 41.02 & 50 & 0 & 4062 & 1 & 1 \\
\hline 41.99 & 1 & 0 & 27 & 0 & 0 \\
\hline 42 & 63 & 0 & 2620 & 1 & 1 \\
\hline 43 & 4 & 0 & 846 & 0 & 0 \\
\hline 43.99 & 1 & 0 & 71 & 0 & 0 \\
\hline 44 & 1 & 0 & 19 & 0 & 0 \\
\hline 44.99 & 18 & 0 & 146 & 0 & 0 \\
\hline
\end{tabular}


TABLE VIII, CONT.

INDEX OF RESIDENTIAL SEGREGATION FOR PORTLAND

1980

\begin{tabular}{|c|c|c|c|c|c|}
\hline TRACT & $\begin{array}{c}\text { NUM } \\
\text { BLACK }\end{array}$ & BLACK & $\begin{array}{c}\text { NUM } \\
\text { WHITE }\end{array}$ & WHITE & DIFF \\
\hline 45 & 31 & 0 & 1413 & 0 & 0 \\
\hline 46.01 & 10 & 0 & 2617 & 1 & 1 \\
\hline 46.02 & 4 & 0 & 1847 & 1 & 1 \\
\hline 47 & 34 & 0 & 3587 & 1 & 1 \\
\hline 48 & 45 & 0 & 2577 & 1 & 1 \\
\hline 49 & 76 & 0 & 2653 & 1 & 1 \\
\hline 50 & 23 & 0 & 479 & 0 & 0 \\
\hline 51 & 100 & 0 & 1140 & 0 & 0 \\
\hline 52 & 84 & 0 & 3248 & 1 & 1 \\
\hline 53 & 76 & 0 & 1781 & 1 & 0 \\
\hline 54 & 8 & 0 & 410 & 0 & 0 \\
\hline 55 & 67 & 0 & 1171 & 0 & 0 \\
\hline 56 & 138 & 0 & 2269 & 1 & 0 \\
\hline 57 & 13 & 0 & 1296 & 0 & 0 \\
\hline 58 & 28 & 0 & 5025 & 2 & 1 \\
\hline 59 & 51 & 0 & 2678 & 1 & 1 \\
\hline 60.01 & 7 & 0 & 1129 & 0 & 0 \\
\hline 60.02 & 14 & 0 & 1919 & 1 & 1 \\
\hline 61 & 1 & 0 & 1701 & 1 & 1 \\
\hline 62 & 26 & 0 & 2682 & 1 & 1 \\
\hline 63 & 34 & 0 & 2572 & 1 & 1 \\
\hline 64.01 & 26 & 0 & 2501 & 1 & 1 \\
\hline 64.02 & 13 & 0 & 2714 & 1 & 1 \\
\hline 65.01 & 36 & 0 & 4356 & 1 & 1 \\
\hline 65.02 & 26 & 0 & 2827 & 1 & 1 \\
\hline 66.01 & 5 & 0 & 2136 & 1 & 1 \\
\hline 66.02 & 110 & 0 & 4073 & 1 & 1 \\
\hline 67.01 & 20 & 0 & 2637 & 1 & 1 \\
\hline 67.02 & 16 & 0 & 2423 & 1 & 1 \\
\hline 68.01 & 13 & 0 & 1337 & 0 & 0 \\
\hline 68.02 & 13 & 0 & 3216 & 1 & 1 \\
\hline 69 & 7 & 0 & 1068 & 0 & 0 \\
\hline 70 & 4 & 0 & 417 & 0 & 0 \\
\hline 71 & 0 & 0 & 24 & 0 & 0 \\
\hline 72 & 5 & 0 & 1243 & 0 & 0 \\
\hline 73 & 4 & 0 & 418 & 0 & 0 \\
\hline 74 & 94 & 0 & 944 & 0 & 0 \\
\hline 75 & 146 & 1 & 720 & 0 & 0 \\
\hline 82.01 & 0 & 0 & 45 & 0 & 0 \\
\hline 83.01 & 0 & 0 & 415 & 0 & 0 \\
\hline
\end{tabular}


56

TABLE VIII, CONT.

INDEX OF RESIDENTIAL SEGREGATION FOR PORTLAND 1980

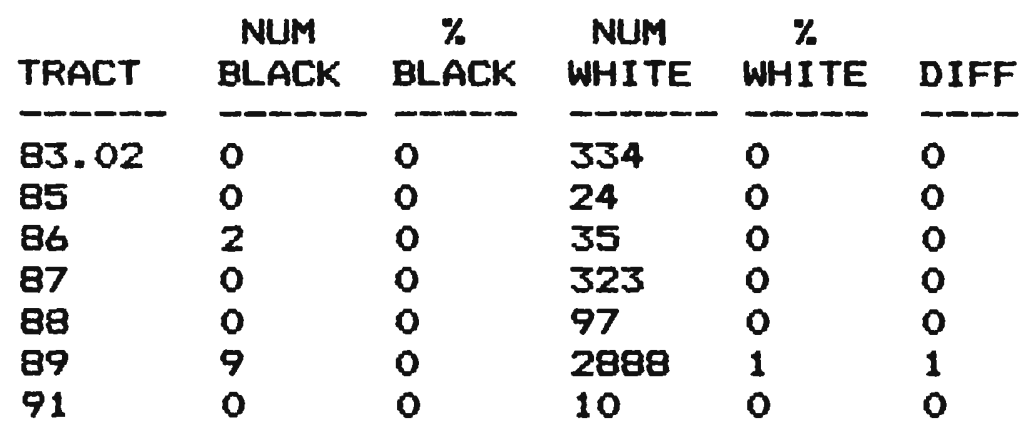

TOTAL BLACKS : 27720 TOTAL WHITES : 315754 AVERAGE BLACKS : 218 AVERAGE WHITES : 2486 TOTAL TRACTS : 127 DELTA :69.5 
TABLE I $X$

INDEX OF RESIDENTIAL SEGREGATION FOR
MULTNOMAH COUNTY 1980

\begin{tabular}{llllll} 
TRACT & NLAM & BLACK & BLACK & $\begin{array}{c}\text { NUM } \\
\text { WHITE }\end{array}$ & $\begin{array}{l}\text { WHITE } \\
\text { DIFF }\end{array}$ \\
\hline 6.01 & 0 & 0 & 382 & 0 & 0 \\
6.02 & 0 & 0 & 127 & 0 & 0 \\
16.02 & 0 & 0 & 445 & 0 & 0 \\
17.02 & 0 & 0 & 159 & 0 & 0 \\
29.01 & 11 & 1 & 623 & 0 & 0 \\
29.03 & 0 & 0 & 146 & 0 & 0 \\
41.01 & 0 & 0 & 8 & 0 & 0 \\
43 & 0 & 0 & 44 & 0 & 0 \\
63 & 1 & 0 & 1405 & 1 & 1 \\
64.01 & 14 & 1 & 1721 & 1 & 0 \\
64.02 & 0 & 0 & 366 & 0 & 0 \\
65.02 & 3 & 0 & 674 & 0 & 0 \\
68.01 & 0 & 0 & 743 & 0 & 0 \\
68.02 & 0 & 0 & 31 & 0 & 0 \\
69 & 1 & 0 & 1209 & 1 & 1 \\
70 & 5 & 0 & 1502 & 1 & 1 \\
71 & 9 & 0 & 2072 & 1 & 1 \\
72 & 16 & 1 & 1657 & 1 & 0 \\
73 & 3 & 0 & 668 & 0 & 0 \\
74 & 159 & 7 & 1288 & 1 & 7 \\
75 & 201 & 9 & 2913 & 2 & 8 \\
76 & 51 & 2 & 2713 & 1 & 1 \\
77 & 10 & 0 & 1741 & 1 & 0 \\
78 & 79 & 4 & 1644 & 1 & 3 \\
79 & 19 & 1 & 3301 & 2 & 1 \\
80.01 & 21 & 1 & 2869 & 2 & 1 \\
80.02 & 18 & 1 & 2748 & 1 & 1 \\
81 & 53 & 2 & 5351 & 3 & 0 \\
82.01 & 37 & 2 & 2224 & 1 & 1 \\
82.02 & 15 & 1 & 4419 & 2 & 2 \\
83.01 & 4 & 0 & 1319 & 1 & 1 \\
83.02 & 20 & 1 & 2486 & 1 & 0 \\
84 & 19 & 1 & 2472 & 1 & 0 \\
85 & 10 & 0 & 2919 & 2 & 1 \\
86 & 46 & 2 & 2786 & 1 & 1 \\
87 & 23 & 1 & 3353 & 2 & 1 \\
88 & 26 & 1 & 3229 & 2 & 0 \\
89 & 10 & 0 & 2237 & 1 & 1 \\
90 & 64 & 3 & 4946 & 3 & 0 \\
91 & 68 & 3 & 6610 & 4 & 0 \\
& & & & &
\end{tabular}


TABLE IX, CONT.

INDEX OF RESIDENTIAL SEGREGATION FOR MULTNOMAH COUNTY

1980

\begin{tabular}{llllll} 
TRACT & $\begin{array}{c}\text { NUM } \\
\text { BLACK }\end{array}$ & BLACK & $\begin{array}{c}\text { NUM } \\
\text { WHITE }\end{array}$ & $\begin{array}{l}\% \\
\text { WHITE }\end{array}$ & DIFF \\
\hline 92.01 & 26 & 1 & 5064 & 3 & 1 \\
92.02 & 25 & 1 & 3483 & 2 & 1 \\
93 & 33 & 2 & 6312 & 3 & 2 \\
94 & 54 & 3 & 5074 & 3 & 0 \\
95 & 192 & 9 & 6349 & 3 & 6 \\
96.01 & 70 & 3 & 5918 & 3 & 0 \\
96.02 & 57 & 3 & 6280 & 3 & 1 \\
97.01 & 38 & 2 & 4500 & 2 & 1 \\
97.02 & 45 & 2 & 6046 & 3 & 1 \\
98.01 & 88 & 4 & 2546 & 1 & 3 \\
98.02 & 27 & 1 & 6460 & 3 & 2 \\
99 & 87 & 4 & 10354 & 5 & 1 \\
100 & 25 & 1 & 4995 & 3 & 1 \\
101 & 54 & 3 & 4681 & 2 & 0 \\
102 & 5 & 0 & 1569 & 1 & 1 \\
103 & 97 & 5 & 7234 & 4 & 1 \\
104.02 & 24 & 1 & 3936 & 2 & 1 \\
104.03 & 110 & 5 & 12429 & 7 & 1 \\
104.04 & 18 & 1 & 3979 & 2 & 1 \\
105 & 33 & 2 & 3600 & 2 & 0
\end{tabular}

TOTAL BLACKS : 2124 TOTAL WHITES : 188359

AVERAGE BLACKS : 35 AVERAGE WHITES : 3139

TOTAL TRACTS : 60 DELTA : 29.5 
TABLE $X$

INDEX OF RESIDENTIAL SEGREGATION FOR CLACKAMAS COUNTY

1980

\begin{tabular}{llllll} 
TRACT & $\begin{array}{c}\text { NUM } \\
\text { BLACK }\end{array}$ & $\begin{array}{l}\text { BLACK } \\
\text { WHITE }\end{array}$ & $\begin{array}{c}\text { NHITE } \\
\text { WHIT }\end{array}$ & DIFF \\
\hline 201 & 12 & 2 & 3676 & 2 & 0 \\
202 & 16 & 2 & 4780 & 2 & 0 \\
203.01 & 25 & 3 & 3727 & 2 & 2 \\
203.02 & 0 & 0 & 2461 & 1 & 1 \\
204.01 & 14 & 2 & 5421 & 2 & 0 \\
204.02 & 18 & 2 & 5833 & 2 & 0 \\
205.01 & 9 & 1 & 3126 & 1 & 0 \\
205.02 & 55 & 7 & 6928 & 3 & 4 \\
206 & 8 & 1 & 4076 & 2 & 1 \\
207 & 14 & 2 & 2354 & 1 & 1 \\
208 & 23 & 3 & 3652 & 2 & 1 \\
209 & 14 & 2 & 3731 & 2 & 0 \\
210 & 8 & 1 & 4659 & 2 & 1 \\
211 & 30 & 4 & 5043 & 2 & 2 \\
212 & 10 & 1 & 3556 & 2 & 0 \\
213 & 11 & 1 & 5063 & 2 & 1 \\
214 & 15 & 2 & 4008 & 2 & 0 \\
215 & 2 & 0 & 3617 & 2 & 1 \\
216.01 & 35 & 5 & 3854 & 2 & 3 \\
216.02 & 13 & 2 & 3544 & 2 & 0 \\
217 & 6 & 1 & 4630 & 2 & 1 \\
218 & 29 & 4 & 8436 & 4 & 0 \\
219 & 8 & 1 & 2597 & 1 & 0 \\
220 & 16 & 2 & 6025 & 3 & 0 \\
221.01 & 28 & 4 & 5762 & 2 & 1 \\
221.02 & 16 & 2 & 4546 & 2 & 0 \\
222.01 & 0 & 0 & 1476 & 1 & 1 \\
222.02 & 39 & 5 & 5330 & 2 & 3 \\
223 & 20 & 3 & 5679 & 2 & 0 \\
224 & 3 & 0 & 3735 & 2 & 1 \\
225 & 13 & 2 & 6230 & 3 & 1 \\
226 & 15 & 2 & 8246 & 3 & 2 \\
227.01 & 16 & 2 & 3930 & 2 & 0 \\
227.02 & 12 & 2 & 2583 & 1 & 0 \\
228 & 0 & 0 & 2334 & 1 & 1 \\
229 & 9 & 1 & 9354 & 4 & 3 \\
230 & 18 & 2 & 6101 & 3 & 0 \\
231 & 19 & 2 & 4940 & 2 & 0 \\
232 & 15 & 2 & 6148 & 3 & 1 \\
233 & 11 & 1 & 4406 & 2 & 0 \\
& & & & &
\end{tabular}


TABLE $X$, CONT.

INDEX OF RESIDENTIAL SEGREGATION FOR CLACKAMAS COUNTY

1980

\begin{tabular}{llllll} 
TRACT & $\begin{array}{l}\text { NUM } \\
\text { BLACK }\end{array}$ & $\begin{array}{c}\text { BLACK } \\
\text { THITE }\end{array}$ & $\begin{array}{c}\text { NUM } \\
\text { WHITE }\end{array}$ & WIFF \\
\hline 234.01 & 2 & 0 & 3811 & 2 & 1 \\
234.02 & 7 & 1 & 4392 & 2 & 1 \\
235 & 14 & 2 & 4995 & 2 & 0 \\
236 & 7 & 1 & 3167 & 1 & 0 \\
237 & 5 & 1 & 4315 & 2 & 1 \\
238 & 2 & 0 & 6601 & 3 & 3 \\
239 & 1 & 0 & 4660 & 2 & 2 \\
240 & 3 & 0 & 2137 & 1 & 1 \\
241 & 2 & 0 & 4384 & 2 & 2 \\
242 & 91 & 12 & 4256 & 2 & 10 \\
243 & 9 & 1 & 7372 & 3 & 2
\end{tabular}

TOTAL BLACKS : 768 TOTAL WHITES : 235687 AVERAGE BLACKS : 15 TOTAL TRACTS : $\mathbf{5 1}$ DELTA : 28 
TABLE XI

$$
\begin{gathered}
\text { INDEX OF RESIDENTIAL SEGREGATION FOR } \\
\text { WASHINGTON COUNTY } \\
1980
\end{gathered}
$$

\begin{tabular}{|c|c|c|c|c|c|}
\hline TRACT & $\begin{array}{l}\text { NUM } \\
\text { BLACK }\end{array}$ & $\begin{array}{c}\% \\
\text { BLACK }\end{array}$ & $\begin{array}{l}\text { NUM } \\
\text { WHITE }\end{array}$ & WHITE & DIFF \\
\hline 301 & 41 & 4 & 5541 & 2 & 1 \\
\hline 302 & 31 & 3 & 5702 & 2 & 0 \\
\hline 303 & 12 & 1 & 4711 & 2 & 1 \\
\hline 304.01 & 16 & 1 & 3786 & 2 & 0 \\
\hline 304.02 & 16 & 1 & 3190 & 1 & 0 \\
\hline 305 & 39 & 4 & 6817 & 3 & 1 \\
\hline 306 & 9 & 1 & 3918 & 2 & 1 \\
\hline 307 & 5 & 0 & 1345 & 1 & 0 \\
\hline 308 & 11 & 1 & 7593 & 3 & 2 \\
\hline 309 & 18 & 2 & 3405 & 1 & 0 \\
\hline 310.01 & 31 & 3 & 8370 & 4 & 1 \\
\hline 310.02 & 93 & 9 & 8199 & 4 & 5 \\
\hline 311 & 13 & 1 & 2079 & 1 & 0 \\
\hline 312 & 56 & 5 & 4963 & 2 & 3 \\
\hline 313 & 69 & 6 & 4713 & 2 & 4 \\
\hline 314.01 & 41 & 4 & 9517 & 4 & 0 \\
\hline 314.02 & 19 & 2 & 876 & 0 & 1 \\
\hline 315.01 & 2 & 0 & 1304 & 1 & 0 \\
\hline 315.02 & 26 & 2 & 7694 & 3 & 1 \\
\hline 315.03 & 44 & 4 & 9149 & 4 & 0 \\
\hline 316.01 & 9 & 1 & 4094 & 2 & 1 \\
\hline 316.02 & 76 & 7 & 10468 & 4 & 2 \\
\hline 317.01 & 48 & 4 & 9153 & 4 & 0 \\
\hline 317.02 & 25 & 2 & 4006 & 2 & 1 \\
\hline 318 & 23 & 2 & 8861 & 4 & 2 \\
\hline 319.01 & 13 & 1 & 5673 & 2 & 1 \\
\hline 319.02 & 27 & 2 & 6604 & 3 & 0 \\
\hline 320 & 68 & 6 & 5883 & 3 & 4 \\
\hline 321.01 & 5 & 0 & 2962 & 1 & 1 \\
\hline 321.02 & 6 & 1 & 3922 & 2 & 1 \\
\hline 322 & 12 & 1 & 3077 & 1 & 0 \\
\hline 323 & 1 & 0 & 2087 & 1 & 1 \\
\hline 324.01 & 45 & 4 & 9797 & 4 & 0 \\
\hline 324.02 & 13 & 1 & 2870 & 1 & 0 \\
\hline 325 & 2 & 0 & 4843 & 2 & 2 \\
\hline 326 & 40 & 4 & 11922 & 5 & 1 \\
\hline 327 & 3 & 0 & 3225 & 1 & 1 \\
\hline 328 & 2 & 0 & 1503 & 1 & 0 \\
\hline 329 & 14 & 1 & 5150 & 2 & 1 \\
\hline 330 & 1 & 0 & 4802 & 2 & 2 \\
\hline
\end{tabular}


TABLE XI, CONT.

INDEX OF RESIDENTIAL SEGREGATION FOR WASHINGTON COUNTY

1980

\begin{tabular}{llllll} 
TRACT & $\begin{array}{l}\text { NUM } \\
\text { BLACK }\end{array}$ & BLACK & $\begin{array}{c}\text { NUM } \\
\text { WHITE }\end{array}$ & WHITE & DIFF \\
\hline 331 & 9 & 1 & 4961 & 2 & 1 \\
332 & 39 & 4 & 3769 & 2 & 2 \\
333 & 3 & 0 & 4709 & 2 & 2 \\
334 & 10 & 1 & 2071 & 1 & 0 \\
335 & 4 & 0 & 2399 & 1 & 1 \\
336 & 1 & 0 & 1939 & 1 & 1
\end{tabular}

TOTAL BLACKS : 1091 TOTAL WHITES : 233622

AVERAGE BLACKS : 24 AVERAGE WHITES : 5079

TOTAL TRACTS : 46 DELTA : $\mathbf{2 4 . 5}$ 
TABLE XI I

INDEX OF RESIDENTIAL SEGREGATION FOR

CLARK COUNTY

1980

\begin{tabular}{|c|c|c|c|c|c|}
\hline TRACT & $\begin{array}{l}\text { NUM } \\
\text { BLACK }\end{array}$ & $\begin{array}{c}\% \\
\text { BLACK }\end{array}$ & $\begin{array}{c}\text { NUM } \\
\text { WHITE }\end{array}$ & $\begin{array}{c}\mathbf{z} \\
\text { WHITE }\end{array}$ & DIFF \\
\hline 401 & 4 & 0 & 3578 & 2 & 2 \\
\hline 402 & 1 & 0 & 6134 & 3 & 3 \\
\hline 403 & 1 & 0 & 2957 & 2 & 2 \\
\hline 404.01 & 31 & 2 & 4783 & 3 & 1 \\
\hline 404.02 & 9 & 1 & 5858 & 3 & 3 \\
\hline 405.01 & 15 & 1 & 5611 & 3 & 2 \\
\hline 405.02 & 2 & 0 & 3092 & 2 & 2 \\
\hline 405.03 & 2 & 0 & 4602 & 2 & 2 \\
\hline 406 & 20 & 1 & 7040 & 4 & 3 \\
\hline 407.01 & 49 & 3 & 8283 & 4 & 2 \\
\hline 407.02 & 2 & 0 & 3243 & 2 & 2 \\
\hline 408.01 & 38 & 2 & 5172 & 3 & 1 \\
\hline 408.02 & 41 & 2 & 4631 & 3 & 0 \\
\hline 409.01 & 112 & 7 & 9028 & 5 & 2 \\
\hline 409.02 & 15 & 1 & 4114 & 2 & 1 \\
\hline 410.02 & 8 & 0 & 4327 & 2 & 2 \\
\hline 410.03 & 22 & 1 & 3267 & 2 & 0 \\
\hline 410.04 & 53 & 3 & 7770 & 4 & 1 \\
\hline 410.05 & 28 & 2 & 1980 & 1 & 1 \\
\hline 411.01 & 115 & 7 & 8713 & 5 & 2 \\
\hline 411.03 & 4 & 0 & 2301 & 1 & 1 \\
\hline 411.04 & 13 & 1 & 1789 & 1 & 0 \\
\hline 412.01 & 53 & 3 & 3193 & 2 & 1 \\
\hline 412.02 & 134 & 8 & 9235 & 5 & 3 \\
\hline 413.01 & 162 & 10 & 6366 & 3 & 6 \\
\hline 413.02 & 135 & 8 & 9258 & 5 & 3 \\
\hline 413.03 & 75 & 4 & 8402 & 5 & 0 \\
\hline 414 & 12 & 1 & 3017 & 2 & 1 \\
\hline 415 & 5 & 0 & 2380 & 1 & 1 \\
\hline 416 & 21 & 1 & 2118 & 1 & 0 \\
\hline 417 & 31 & 2 & 2752 & 1 & 0 \\
\hline 418 & 24 & 1 & 3144 & 2 & 0 \\
\hline 419 & 13 & 1 & 1803 & 1 & 0 \\
\hline 420 & 10 & 1 & 1418 & 1 & 0 \\
\hline 421 & 38 & 2 & 2328 & 1 & 1 \\
\hline 423 & 56 & 3 & 2566 & 1 & 2 \\
\hline 424 & 12 & 1 & 657 & 0 & 0 \\
\hline 425 & 14 & 1 & 1152 & 1 & 0 \\
\hline 426 & 41 & 2 & 3237 & 2 & 1 \\
\hline 427 & 68 & 4 & 2967 & 2 & 2 \\
\hline
\end{tabular}


TABLE XII, CONT.

INDEX OF RESIDENTIAL SEGREGATION FOR CLARK COUNTY

1980

\begin{tabular}{lllllll} 
& NUM & $\%$ & NUM & $\%$ & \\
TRACT & BLACK & BLACK & WHITE & WHITE & DIFF \\
\hline-128 & 76 & 5 & 2748 & 1 & 3 \\
429 & 18 & 1 & 2273 & 1 & 0 \\
430 & 39 & 2 & 1799 & 1 & 1 \\
431 & 60 & 4 & 3741 & 2 & 2
\end{tabular}

TOTAL BLACKS : 1682 TOTAL WHITES : 184827

AVERAGE BLACKS: 38 AVERAGE WHITES: 4201

TOTAL TRACTS : 44 DELTA : 31 
TABLE XV

INDEX OF INCOME SEGREGATION FOR TRACTS WITH 400 OR MORE BLACKS 1970

\begin{tabular}{|c|c|c|c|c|c|c|}
\hline FAMILY & INCOME & $\begin{array}{c}\text { NUM } \\
\text { BLACK }\end{array}$ & $\begin{array}{c}\% \\
\text { BLACK }\end{array}$ & $\begin{array}{c}\text { NUM } \\
\text { WHITE }\end{array}$ & WHITE & DIFF \\
\hline $\begin{array}{l}\text { UNDER } \\
1,000 \\
2,000 \\
3,000 \\
4,000 \\
5,000 \\
6,000 \\
7,000 \\
8,000 \\
9,000 \\
\text { ABOVE }\end{array}$ & $\begin{array}{l}1000 \\
-1,999 \\
-2,999 \\
-3,999 \\
-4,999 \\
-5,999 \\
-6,999 \\
-7,999 \\
-8,999 \\
-9,999 \\
10,000\end{array}$ & $\begin{array}{l}205 \\
294 \\
300 \\
300 \\
349 \\
332 \\
356 \\
303 \\
277 \\
252 \\
1108\end{array}$ & $\begin{array}{l}5 \\
7 \\
7 \\
7 \\
9 \\
8 \\
9 \\
7 \\
7 \\
6 \\
27\end{array}$ & $\begin{array}{l}179 \\
249 \\
480 \\
371 \\
416 \\
427 \\
518 \\
461 \\
547 \\
582 \\
3323\end{array}$ & $\begin{array}{l}2 \\
3 \\
6 \\
5 \\
6 \\
6 \\
7 \\
6 \\
7 \\
8 \\
44\end{array}$ & $\begin{array}{l}3 \\
4 \\
1 \\
2 \\
3 \\
2 \\
2 \\
1 \\
0 \\
2 \\
17\end{array}$ \\
\hline
\end{tabular}

TOTAL BLACKS : 4076 AVERAGE BLACKS : 371 DELTA : 18.5
TOTAL WHITES : 7553

AVERAGE WHITES : 687

TABLE XVI

INDEX OF INCOME SEGREGATION FOR PORTLAND

1970

NUM $\%$ NUM $\%$

FAMILY INCOME BLACK BLACK WHITE WHITE DIFF

UNDER 1000

$\begin{array}{ll}244 & 5 \\ 343 & 7 \\ 325 & 7 \\ 366 & 8 \\ 418 & 9 \\ 389 & 8 \\ 403 & 8 \\ 363 & 7 \\ 353 & 7 \\ 290 & 6 \\ 1356 & 28\end{array}$

$\begin{array}{ccc}-1557 & 2 & 3 \\ 2107 & 2 & 5 \\ 4039 & 4 & 2 \\ 4204 & 5 & 3 \\ 4450 & 5 & 4 \\ 4865 & 5 & 3 \\ 5367 & 6 & 2 \\ 6050 & 7 & 1 \\ 6897 & 8 & 0 \\ 6818 & 7 & 1 \\ 45563 & 50 & 22\end{array}$

TOTAL BLACKS : 4850 TOTAL WHITES : 91917 AVERAGE BLACKS : 441 AVERAGE WHITES : 8356 DELTA : 23 
TABLE XVII

INDEX OF INCOME SEGREGATION FOR MULTNOMAH COUNTY

1970

\begin{tabular}{|c|c|c|c|c|c|c|}
\hline FAMILY & Y INCOME & $\begin{array}{c}\text { NUM } \\
\text { BLACK }\end{array}$ & BLACK & $\begin{array}{c}\text { NUM } \\
\text { WHITE }\end{array}$ & $\begin{array}{c}\% \\
\text { WHITE }\end{array}$ & DIFF \\
\hline UNDER & 1000 & 0 & 0 & 702 & 2 & 2 \\
\hline 1,000 & $-1,999$ & 5 & 5 & 1001 & 2 & 3 \\
\hline 2,000 & $-2,999$ & 0 & 0 & 1205 & 3 & 3 \\
\hline 3,000 & $-3,999$ & 5 & 5 & 1704 & 4 & 2 \\
\hline 4,000 & $-4,999$ & 5 & 5 & 1791 & 4 & 2 \\
\hline 5,000 & $-5,999$ & 12 & 13 & 1855 & 4 & 9 \\
\hline 6,000 & $-6,999$ & 6 & 7 & 2235 & 5 & 2 \\
\hline 7,000 & $-7,999$ & 0 & 0 & 2673 & 6 & 6 \\
\hline 8,000 & $-8,999$ & 4 & 4 & 3445 & 7 & 3 \\
\hline 9,000 & $-9,999$ & 6 & 7 & 3549 & 8 & 1 \\
\hline ABOVE & 10,000 & 48 & 53 & 25892 & 56 & 3 \\
\hline
\end{tabular}

TOTAL BLACKS :91 TOTAL WHITES : 46052

AVERAGE BLACKS : 8 AVERAGE WHITES : 4187

DELTA : 18

TABLE XVIII

INDEX OF INCOME SEGREGATION FOR

CLACKAMAS COUNTY

1970

\begin{tabular}{lccccc} 
FAMILY INCOME & $\begin{array}{c}\text { NUM } \\
\text { BLACK }\end{array}$ & $\begin{array}{c}\% \\
\text { BLACK }\end{array}$ & $\begin{array}{c}\text { NUM } \\
\text { WHITE }\end{array}$ & WHITE & DIFF \\
\hline UNDER 1000 & -10 & 18 & 739 & 2 & -16 \\
$1,000-1,999$ & 0 & 0 & 887 & 2 & 2 \\
$2,000-2,999$ & 5 & 9 & 1363 & 3 & 6 \\
$3,000-3,999$ & 0 & 0 & 1561 & 4 & 4 \\
$4,000-4,999$ & 4 & 7 & 1676 & 4 & 3 \\
$5,000-5,999$ & 0 & 0 & 1720 & 4 & 4 \\
$6,000-6,999$ & 5 & 9 & 2109 & 5 & 4 \\
$7,000-7,999$ & 0 & 0 & 2827 & 7 & 7 \\
$8,000-8,999$ & 0 & 0 & 3299 & 8 & 8 \\
$9,000-9,999$ & 7 & 13 & 3129 & 7 & 5 \\
ABOVE 10,000 & 25 & 45 & 23964 & 55 & 11
\end{tabular}

TOTAL BLACKS : 56 TOTAL WHITES : 43274

AVERAGE BLACKS : 5 AVERAGE WHITES : 3934

DELTA : 35 
TABLE $X I X$

INDEX OF INCOME SEGREGATION FOR

WASHINGTON COUNTY

1970

\begin{tabular}{llcccc} 
FAMILY INCOME & $\begin{array}{c}\text { NUM } \\
\text { BLACK }\end{array}$ & $\begin{array}{c}\% \\
\text { BLACK }\end{array}$ & $\begin{array}{c}\text { NHIM } \\
\text { WHI }\end{array}$ & WHITE & DIFF \\
\hline UNDER 1000 & 0 & 0 & 457 & 1 & 1 \\
$1,000-1,999$ & 0 & 0 & 619 & 1 & 1 \\
$2,000-2,999$ & 0 & 0 & 1035 & 2 & 2 \\
$3,000-3,999$ & 0 & 0 & 1139 & 3 & 3 \\
$4,000-4,999$ & 6 & 25 & 1422 & 3 & 22 \\
$5,000-5,999$ & 0 & 0 & 1478 & 4 & 4 \\
$6,000-6,999$ & 0 & 0 & 1850 & 4 & 4 \\
$7,000-7,999$ & 4 & 17 & 2528 & 6 & 11 \\
$8,000-8,999$ & 0 & 0 & 2528 & 6 & 6 \\
9, OOO - 9,999 & 5 & 21 & 2928 & 7 & 14 \\
ABOVE 10,000 & 9 & 38 & 25462 & 61 & 24
\end{tabular}

TOTAL BLACKS : 24 TOTAL WHITES : 41446

AVERAGE BLACKS : 2 AVERAGE WHITES : 3768

DELTA : 46

TABLE $X X$

INDEX OF INCOME SEGREGATION FOR

CLARK COUNTY

1970

FAMILY INCOME

UNDER 1000

$2,000-2,999$

$3,000-3,999$

$4,000-4,999$

$5,000-5,999$

$6,000-6,999$

$7,000-7,999$

$8,000-8,999$

$9,000-9,999$

ABDVE 10,000
$1,000-1,999$

NUM BLACK

7
7
8
21
4
13
8
4
27
0
52

TOTAL BLACKS : 151

TOTAL WHITES : 33538

AVERAGE BLACKS : 14

DELTA : 31.5
$\%$ NUM \% BLACK WHITE WHITE DIFF

$\begin{array}{llll}-5 & -1-1 & - & - \\ 5 & 600 & 2 & 3 \\ 5 & 1210 & 2 & 2 \\ 14 & 1241 & 4 & 2 \\ 3 & 1421 & 4 & 10 \\ 9 & 1361 & 4 & 5 \\ 5 & 1900 & 6 & 0 \\ 3 & 2303 & 7 & 4 \\ 18 & 2738 & 8 & 10 \\ 0 & 2714 & 8 & 8 \\ 34 & 17284 & 52 & 17\end{array}$




\section{TABLE $X X I$}

INDEX OF INCOME SEGREGATION FOR

THE SMSA

1970

\begin{tabular}{lcccccc} 
FAMILY INCOME & NUM & $\%$ & NUM & $\%$ & \\
\hline UNDER 1000 & -2 ACK & BLACK & WHITE & WHITE & DIFF \\
$1,000-1,999$ & 261 & 5 & 4055 & 2 & 3 \\
$2,000-2,999$ & 355 & 7 & 5380 & 2 & 5 \\
$3,000-3,999$ & 338 & 7 & 8858 & 3 & 3 \\
$4,000-4,999$ & 392 & 8 & 9854 & 4 & 4 \\
$5,000-5,999$ & 437 & 8 & 10772 & 4 & 4 \\
$6,000-6,999$ & 414 & 8 & 11285 & 4 & 4 \\
$7,000-7,999$ & 422 & 8 & 13461 & 5 & 3 \\
$8,000-8,999$ & 371 & 7 & 16381 & 6 & 1 \\
$9,000-9,999$ & 384 & 7 & 18907 & 7 & 0 \\
ABOVE 10,000 & 308 & 6 & 19156 & 7 & 2 \\
& 1490 & 29 & 138272 & 54 & 25
\end{tabular}

TOTAL BLACKS : 5172 AVERAGE BLACKS : 470 DELTA : 27
TOTAL WHITES : 256381

AVERAGE WHITES : 23307 
TABLE $\times X I I$

INDEX OF INCOME SEGREGATION FOR TRACTS WITH 400 OR MORE BLACKS 1980

\begin{tabular}{lcccccc} 
FAMILY INCOME & $\begin{array}{c}\text { NUM } \\
\text { BLACK }\end{array}$ & $\begin{array}{c}\% \\
\text { BLACK }\end{array}$ & $\begin{array}{c}\text { NUM } \\
\text { WHTE }\end{array}$ & WHITE & DIFF \\
\hline UNDER 5000 & 1460 & 23 & 1997 & 14 & 8 \\
$5,000-7,499$ & 754 & 12 & 1258 & 9 & 3 \\
$7,500-9,999$ & 679 & 11 & 1308 & 9 & 1 \\
$10,000-14,999$ & 976 & 15 & 2251 & 16 & 1 \\
$15,000-19,999$ & 784 & 12 & 2065 & 15 & 3 \\
$20,000-24,999$ & 667 & 10 & 1774 & 13 & 2 \\
$25,000-34,999$ & 704 & 11 & 2009 & 15 & 4 \\
$35,000-49,999$ & 270 & 4 & 845 & 6 & 2 \\
ABOVE 50,000 & 74 & 1 & 279 & 2 & 1
\end{tabular}

TOTAL BLACKS : 6368 TOTAL WHITES : 13786 AVERAGE BLACKS : 708 AVERAGE WHITES : 1532 DELTA : 12.5

TABLE XXIII

INDEX OF INCOME SEGREGATION FOR PORTLAND

1980

FAMILY INCOME

\section{UNDER 5000}

$5,000-7,499$

$7,500-9,999$

$10,000-14,999$

$15,000-19,999$

$20,000-24,999$

$25,000-34,999$

$35,000-49,999$

ABQVE 50,000
NUM $\%$ NUM $\%$ BLACK BLACK WHITE WHITE DIFF

$\begin{array}{lllll}2402 & 24 & 21087 & 15 & 9 \\ 1182 & 12 & 13354 & 9 & 2 \\ 1051 & 11 & 13242 & 9 & 1 \\ 1609 & 16 & 23081 & 16 & 0 \\ 1385 & 14 & 20104 & 14 & 0 \\ 908 & 9 & 16062 & 11 & 2 \\ 924 & 9 & 19640 & 14 & 5 \\ 400 & 4 & 10372 & 7 & 3 \\ 130 & 1 & 5566 & 4 & 3\end{array}$

TOTAL BLACKS : 9991 TOTAL WHITES : 142508 AVERAGE BLACKS : 1110 AVERAGE WHITES : 15834 DELTA : 12.5 
TABLE $X X I V$

INDEX OF INCOME SEGREGATION FOR MULTNOMAH COUNTY

1980

\begin{tabular}{lccccc} 
FAMILY INCOME & $\begin{array}{c}\text { NUM } \\
\text { BLACK }\end{array}$ & $\begin{array}{c}\% \\
\text { BLACK }\end{array}$ & $\begin{array}{c}\text { NUM } \\
\text { WHIE }\end{array}$ & WHITE & DIFF \\
\hline UNDER 5000 & -142 & 23 & 6591 & 9 & -14 \\
$5,000-7,499$ & 82 & 13 & 5064 & 7 & 6 \\
$7,500-9,999$ & 27 & 4 & 5135 & 7 & 3 \\
$10,000-14,999$ & 79 & 13 & 10759 & 15 & 2 \\
$15,000-19,999$ & 64 & 10 & 10745 & 15 & 5 \\
$20,000-24,999$ & 69 & 11 & 10469 & 14 & 3 \\
$25,000-34,999$ & 93 & 15 & 13834 & 19 & 4 \\
$35,000-49,999$ & 51 & 8 & 6734 & 9 & 1 \\
ABOVE 50,000 & 14 & 2 & 3088 & 4 & 2
\end{tabular}

TOTAL BLACKS : 621 TOTAL WHITES : 72419

AVERAGE BLACKS : 69 AVERAGE WHITES : 8047

DELTA : 20

TABLE $\times \times V$

INDEX OF INCOME SEGREGATION FOR CLACKAMAS COUNTY 1980

\begin{tabular}{llllll} 
FAMILY INCOME & NLAM & $\%$ & NUM & $\%$ & \\
\hline UNDER 5000 & BLACK & WHITE & WHITE & DIFF \\
$5,000-7,499$ & 4 & 0 & 6255 & 8 & 8 \\
$7,500-9,999$ & 15 & 2 & 4860 & 6 & 4 \\
$10,000-14,999$ & 22 & 9 & 4965 & 6 & 0 \\
$15,000-19,999$ & 41 & 16 & 11269 & 13 & 4 \\
$20,000-24,999$ & 37 & 15 & 12178 & 15 & 0 \\
$25,000-34,999$ & 72 & 28 & 16943 & 20 & 8 \\
35, 000- 49,999 & 46 & 18 & 10271 & 12 & 6 \\
ABOVE 50,000 & 16 & 6 & 5297 & 6 & 0
\end{tabular}

TOTAL BLACKS : 253 TOTAL WHITES : 82828 AVERAGE BLACKS : 28 AVERAGE WHITES : 9203 DELTA : 16.5 
TABLE XXVI

INDEX OF INCOME SEGREGATION FOR WASHINGTON COUNTY

1980

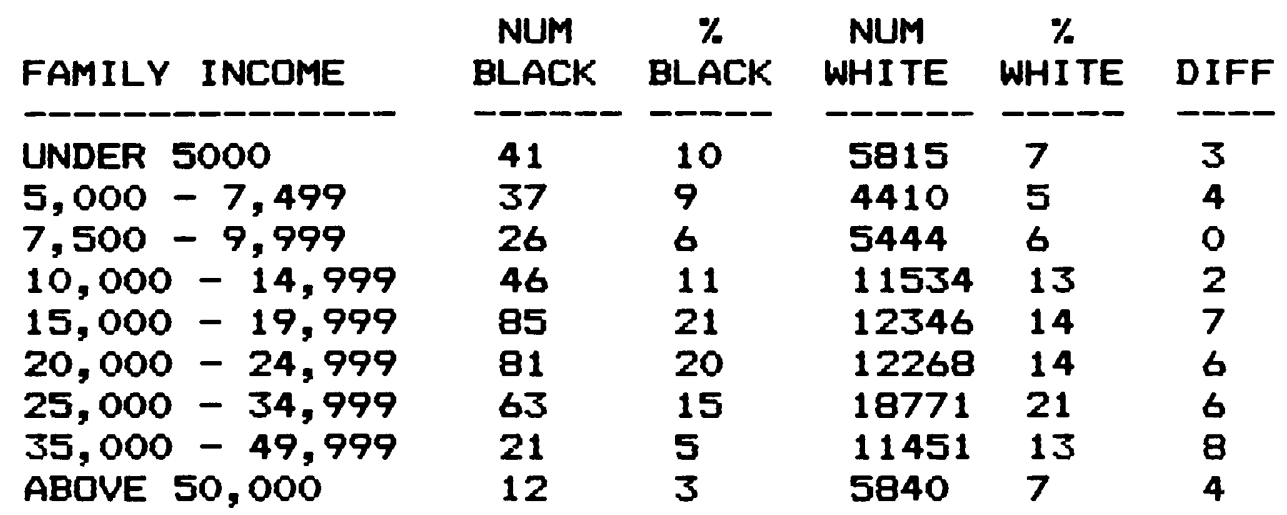

TOTAL BLACKS : 412 TOTAL WHITES : 87879

AVERAGE BLACKS : 46 AVERAGE WHITES : 9764

DELTA : 20

\author{
TABLE XXVI I \\ INDEX OF INCOME SEGREGATION FOR \\ CLARK COUNTY \\ 1980
}

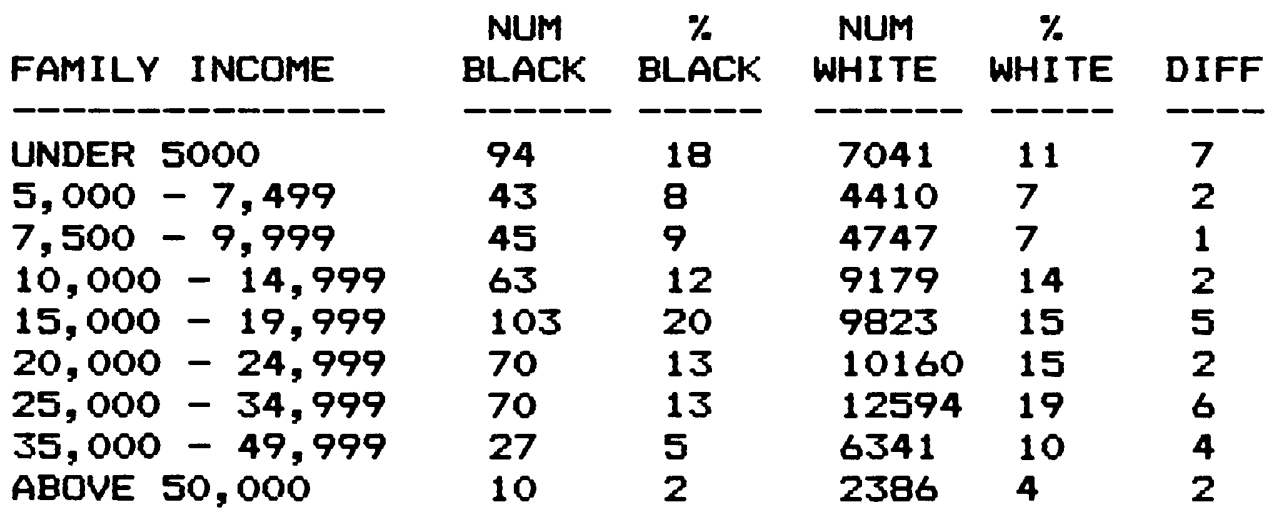

TOTAL BLACKS : 525 TOTAL WHITES : 66681

AVERAGE BLACKS : 58 AVERAGE WHITES : 7409

DELTA : 15.5 
TABLE XXVIII

INDEX OF INCOME SEGREGATION FOR

THE SMSA

1980

\begin{tabular}{lccccc} 
FAMILY INCOME & $\begin{array}{c}\text { NUM } \\
\text { BLACK }\end{array}$ & $\begin{array}{c}\% \\
\text { BLACK }\end{array}$ & $\begin{array}{c}\text { WUI } \\
\text { WHE }\end{array}$ & WHITE & DIFF \\
\hline UNDER 5000 & -2679 & 23 & 46789 & 10 & 12 \\
$5,000-7,499$ & 1348 & 11 & 32098 & 7 & 4 \\
$7,500-9,999$ & 1164 & 10 & 33533 & 7 & 2 \\
$10,000-14,999$ & 1819 & 15 & 65343 & 14 & 1 \\
$15,000-19,999$ & 1678 & 14 & 64287 & 14 & 0 \\
$20,000-24,999$ & 1165 & 10 & 61137 & 14 & 4 \\
$25,000-34,999$ & 1222 & 10 & 81782 & 18 & 8 \\
$35,000-49,999$ & 545 & 5 & 45169 & 10 & 5 \\
ABOVE 50,000 & 182 & 2 & 22177 & 5 & 3
\end{tabular}

TOTAL BLACKS : 11802 TOTAL WHITES : 452315

AVERAGE BLACKS : 1311 AVERAGE WHITES : 50257

DELTA : 19.5 
TABLE $X X I X$

RESIDENTIAL SEGREGATION OF HIGHER STATUS BLACKS

VS WHITES

\begin{tabular}{|c|c|c|c|c|c|}
\hline TRACT & $\begin{array}{c}\text { NUM } \\
\text { BLACK }\end{array}$ & $\begin{array}{c}\% \\
\text { BLACK }\end{array}$ & $\begin{array}{c}\text { NUM } \\
\text { WHITE }\end{array}$ & $\begin{array}{c}\% \\
\text { WHITE }\end{array}$ & DIFF \\
\hline 3.02 & 2 & 1 & 6465 & 3 & 2 \\
\hline 8.01 & 1 & 1 & 4084 & 2 & 1 \\
\hline 10 & 2 & 1 & 4928 & 3 & 1 \\
\hline 20 & 1 & 1 & 4787 & 3 & 2 \\
\hline 22.01 & 2 & 1 & 177 & 0 & 1 \\
\hline 22.02 & 3 & 2 & 94 & 0 & 2 \\
\hline 23.01 & 5 & 4 & 708 & 0 & 3 \\
\hline 23.02 & 2 & 1 & 662 & 0 & 1 \\
\hline 24.01 & 12 & 9 & 1825 & 1 & 8 \\
\hline 24.02 & 2 & 1 & 2327 & 1 & 0 \\
\hline 25.02 & 2 & 1 & 3447 & 2 & 0 \\
\hline 26 & 1 & 1 & 2640 & 1 & 1 \\
\hline 30 & 2 & 1 & 4015 & 2 & 1 \\
\hline 31 & 4 & 3 & 3876 & 2 & 1 \\
\hline 32 & 6 & 4 & 2447 & 1 & 3 \\
\hline 33.01 & 5 & 4 & 810 & 0 & 3 \\
\hline 33.02 & 5 & 4 & 814 & 0 & 3 \\
\hline 34.01 & 10 & 7 & 849 & 0 & 7 \\
\hline 34.02 & 3 & 2 & 374 & 0 & 2 \\
\hline 35.01 & 2 & 1 & 2644 & 1 & 0 \\
\hline 36.01 & 5 & 4 & 1814 & 1 & 3 \\
\hline 36.02 & 18 & 13 & 3735 & 2 & 11 \\
\hline 36.03 & 1 & 1 & 1357 & 1 & 0 \\
\hline 37.01 & 3 & 2 & 2815 & 2 & 1 \\
\hline 37.02 & 3 & 2 & 1644 & 1 & 1 \\
\hline 38.02 & 2 & 1 & 2587 & 1 & 0 \\
\hline 39.01 & 2 & 1 & 4583 & 2 & 1 \\
\hline 39.02 & $\overline{1}$ & 1 & 2979 & $\overline{2}$ & 1 \\
\hline 47 & 2 & 1 & 3587 & 2 & 0 \\
\hline 53 & 1 & 1 & 1781 & 1 & 0 \\
\hline 54 & 1 & 1 & 410 & 0 & 1 \\
\hline 56 & 1 & 1 & 2269 & 1 & 0 \\
\hline 60.02 & 1 & 1 & 1919 & 1 & 0 \\
\hline 63 & 1 & 1 & 2572 & 1 & 1 \\
\hline 65.02 & 1 & 1 & 2827 & 2 & 1 \\
\hline 66.02 & 1 & 1 & 4073 & $\overline{2}$ & 1 \\
\hline 72 & 1 & 1 & 1243 & 1 & 0 \\
\hline 74 & 2 & 1 & 944 & 1 & 1 \\
\hline 80.01 & 1 & 1 & 2869 & 2 & 1 \\
\hline 95 & 3 & 2 & 6349 & $\overline{3}$ & 1 \\
\hline
\end{tabular}


TABLE $X X I X$, CONT.

\section{RESIDENTIAL SEGREGATION OF HIGHER STATUS BLACKS \\ VS WHITES}

\begin{tabular}{llllll} 
TRACT & BLACK & BLACK & $\begin{array}{c}\text { NUM } \\
\text { WHITE }\end{array}$ & $\begin{array}{c}\text { WHITE } \\
\text { DIFF }\end{array}$ & DIH \\
\hline 96.02 & 1 & 1 & 6280 & 3 & 3 \\
98.02 & 1 & 1 & 6460 & 3 & 3 \\
201 & 1 & 1 & 3676 & 2 & 1 \\
209.02 & 1 & 1 & 3731 & 2 & 1 \\
222.02 & 1 & 1 & 5330 & 3 & 2 \\
302 & 1 & 1 & 5702 & 3 & 2 \\
310.01 & 1 & 1 & 8370 & 5 & 4 \\
315.03 & 1 & 1 & 9149 & 5 & 4 \\
319.02 & 1 & 1 & 6604 & 4 & 3 \\
409.01 & 3 & 2 & 9028 & 5 & 3 \\
411.01 & 1 & 1 & 8713 & 5 & 4 \\
412.02 & 1 & 1 & 9235 & 5 & 4 \\
426 & 1 & 1 & 3237 & 2 & 1
\end{tabular}

TOTAL BLACKS : 138 TOTAL WHITES : 185845 AVERAGE BLACKS: 3 AVERAGE WHITES : 3507 TOTAL TRACTS : 53 DELTA : $\mathbf{5 1}$ 
TABLE $X X X$

RESIDENTIAL SEGREGATION OF

BLACKS VS. WHITES

\begin{tabular}{|c|c|c|c|c|c|}
\hline TRACT & $\begin{array}{l}\text { NUM } \\
\text { BLACK }\end{array}$ & BLACK & $\begin{array}{c}\text { NUM } \\
\text { WHITE }\end{array}$ & WHITE & DIFF \\
\hline 3.02 & 18 & 0 & 6465 & 3 & 3 \\
\hline 8.01 & 52 & 0 & 4084 & 2 & 2 \\
\hline 10 & 174 & 1 & 4928 & 3 & 2 \\
\hline 20 & 188 & 1 & 4787 & 3 & 2 \\
\hline 22.01 & 145 & 1 & 177 & 0 & 1 \\
\hline 22.02 & 78 & 0 & 94 & 0 & 0 \\
\hline 23.01 & 1446 & 6 & 708 & 0 & 6 \\
\hline 23.02 & 308 & 1 & 662 & 0 & 1 \\
\hline 24.01 & 1197 & 5 & 1825 & 1 & 4 \\
\hline 24.02 & 264 & 1 & 2327 & 1 & 0 \\
\hline 25.02 & 175 & 1 & 3447 & 2 & 1 \\
\hline 26 & 34 & 0 & 2640 & 1 & 1 \\
\hline 30 & 175 & 1 & 4015 & 2 & 1 \\
\hline 31 & 687 & 3 & 3876 & 2 & 1 \\
\hline 32 & 1596 & 7 & 2447 & 1 & 5 \\
\hline 33.01 & 1802 & 8 & 810 & 0 & 7 \\
\hline 33.02 & 1883 & 8 & 814 & 0 & 7 \\
\hline 34.01 & 2300 & 10 & 849 & 0 & 9 \\
\hline 34.02 & 2167 & 9 & 374 & 0 & 9 \\
\hline 35.01 & 534 & 2 & 2644 & 1 & 1 \\
\hline 36.01 & 2063 & 9 & 1814 & 1 & 8 \\
\hline 36.02 & 2176 & 9 & 3735 & 2 & 7 \\
\hline 36.03 & 248 & 1 & 1357 & 1 & 0 \\
\hline 37.01 & 758 & 3 & 2815 & 2 & 2 \\
\hline 37.02 & 842 & 4 & 1644 & 1 & 3 \\
\hline 38.02 & 137 & 1 & 2587 & 1 & 1 \\
\hline 39.01 & 910 & 4 & 4583 & 2 & 1 \\
\hline 39.02 & 51 & 0 & 2979 & 2 & 1 \\
\hline 47 & 34 & 0 & 3587 & 2 & 2 \\
\hline 53 & 76 & 0 & 1781 & 1 & 1 \\
\hline 54 & 8 & 0 & 410 & 0 & 0 \\
\hline 56 & 138 & 1 & 2269 & 1 & 1 \\
\hline 60.02 & 14 & 0 & 1919 & 1 & 1 \\
\hline 63 & 34 & 0 & 2572 & 1 & 1 \\
\hline 65.02 & 26 & 0 & 2827 & 2 & 1 \\
\hline 66.02 & 110 & 0 & 4073 & 2 & 2 \\
\hline 72 & 5 & 0 & 1243 & 1 & 1 \\
\hline 74 & 94 & 0 & 944 & 1 & 0 \\
\hline 80.01 & 21 & 0 & 2869 & 2 & 1 \\
\hline & 192 & 1 & 6349 & 3 & 3 \\
\hline 96.02 & 57 & 0 & 6280 & 3 & 3 \\
\hline
\end{tabular}


TABLE $X X X$, CONT.

RESIDENTIAL SEGREGATION OF

BLACKS VS. WHITES

\begin{tabular}{llllll} 
TRACT & $\begin{array}{c}\text { NUM } \\
\text { BLACK }\end{array}$ & $\begin{array}{c}\% \\
\text { BLACK }\end{array}$ & $\begin{array}{c}\text { NUM } \\
\text { WHITE }\end{array}$ & $\begin{array}{l}\% \\
\text { WHITE }\end{array}$ & DIFF \\
\hline 98.02 & 27 & 0 & 6460 & 3 & 3 \\
201 & 12 & 0 & 3676 & 2 & 2 \\
209.02 & 14 & 0 & 3731 & 2 & 2 \\
222.02 & 39 & 0 & 5330 & 3 & 3 \\
302 & 31 & 0 & 5702 & 3 & 3 \\
310.01 & 31 & 0 & 8370 & 5 & 4 \\
315.03 & 44 & 0 & 9149 & 5 & 5 \\
319.02 & 27 & 0 & 6604 & 4 & 3 \\
409.01 & 112 & 0 & 9028 & 5 & 4 \\
411.01 & 115 & 0 & 8713 & 5 & 4 \\
412.02 & 134 & 1 & 9235 & 5 & 4 \\
426 & 41 & 0 & 3237 & 2 & 2
\end{tabular}

TOTAL BLACKS : 23844 TOTAL WHITES : 185845 AVERAGE BLACKS : 450 AVERAGE WHITES : 3507 TOTAL TRACTS : 53 DELTA :71 
77

TABLE $X \times X I$

RESIDENTIAL SEGREGATION OF HIGHER STATUS BLACKS VS. BLACKS

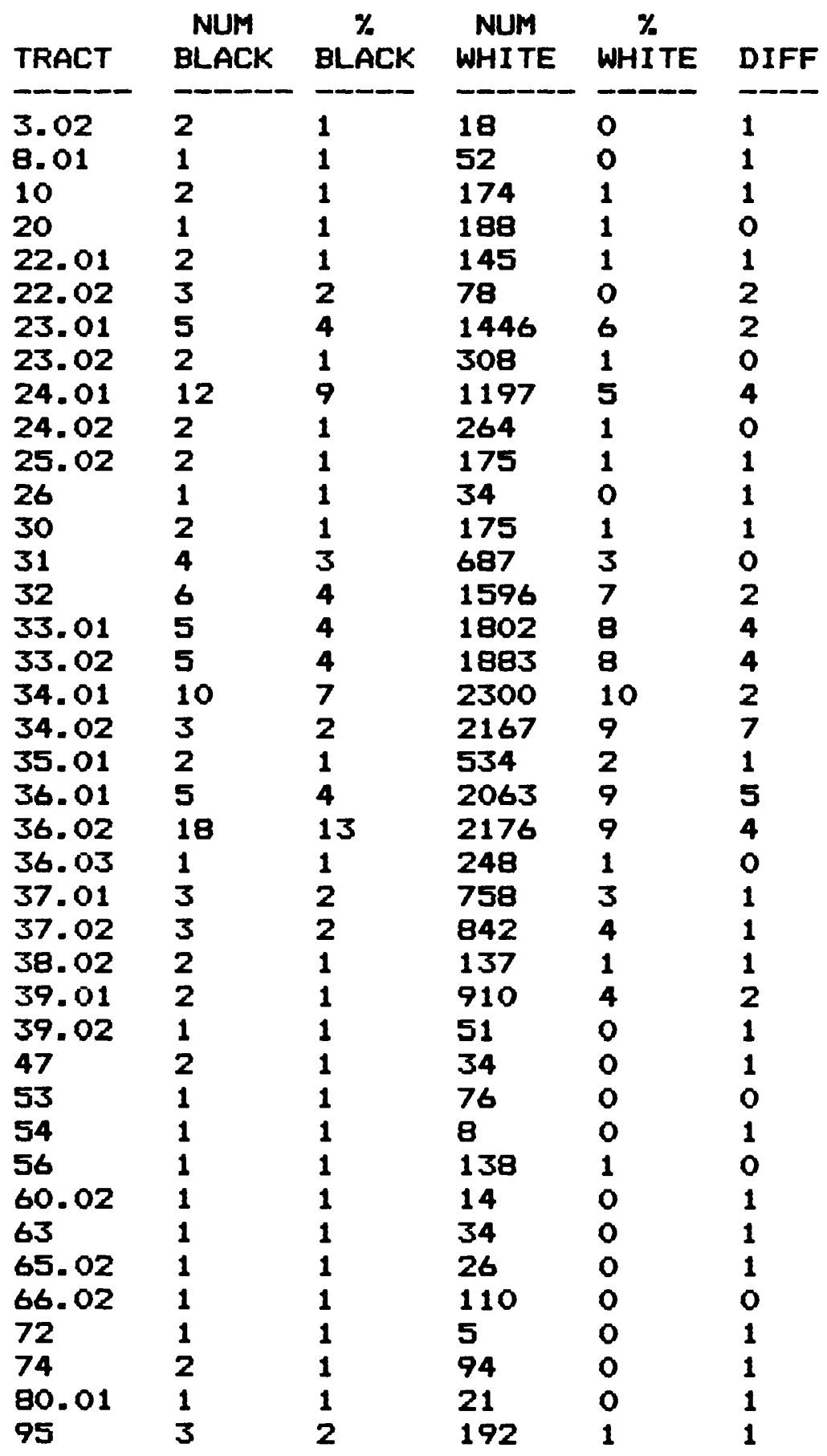


TABLE $X X X I$, CONT.

RESIDENTIAL SEGREGATION OF HIGHER STATUS BLACKS

VS. BLACKS

\begin{tabular}{|c|c|c|c|c|c|}
\hline TRACT & $\begin{array}{l}\text { NUM } \\
\text { BLACK }\end{array}$ & $\begin{array}{c}\% \\
\text { BLACK }\end{array}$ & $\begin{array}{l}\text { NUM } \\
\text { WHITE }\end{array}$ & $\underset{\text { WHITE }}{\boldsymbol{\psi}}$ & DIFF \\
\hline 96.02 & 1 & 1 & 57 & 0 & 0 \\
\hline 98.02 & 1 & 1 & 27 & 0 & 1 \\
\hline 201 & 1 & 1 & 12 & 0 & 1 \\
\hline 209.02 & 1 & 1 & 14 & 0 & 1 \\
\hline 222.02 & 1 & 1 & 39 & 0 & 1 \\
\hline 302 & 1 & 1 & 31 & 0 & 1 \\
\hline 310.01 & 1 & 1 & 31 & 0 & 1 \\
\hline 315.03 & 1 & 1 & 44 & 0 & 1 \\
\hline 319.02 & 1 & 1 & 27 & 0 & 1 \\
\hline 409.01 & 3 & 2 & 112 & 0 & 2 \\
\hline 411.01 & 1 & $\overline{1}$ & 115 & 0 & $\overline{0}$ \\
\hline 412.02 & 1 & 1 & 134 & 1 & 0 \\
\hline 426 & 1 & 1 & 41 & 0 & 1 \\
\hline
\end{tabular}

TOTAL BLACKS : 138 TOTAL WHITES : 23844

AVERAGE BLACKS : 3 AVERAGE WHITES : 450

TOTAL TRACTS : 53 DELTA : 35 